\title{
PERAN KEPEMIMPINAN KELOMPOK TANI DAN EFEKTIVITAS PEMBERDAYAAN PETANI
}

\author{
The Leadership Role of Farmer Groups and Effectiveness of the Farmers Empowerment
}

\author{
Rika Mutmainah*) dan Sumardjo \\ Departemen Sains Komunikasi dan Pengembangan Masyarakat, Fakultas Ekologi Manusia, IPB \\ *)Email : muth.rika93@gmail.com
}

\begin{abstract}
The powerlessness of farmers is caused by the farmers are not able enough to use the equipment of production optimally. The powerlessness is also caused by the unqualified farmers in marketing their agricultural production. Through the farmer groups, the government has a potential to do the learning process and the empowerment to improve their quality of life. In this empowerment process of the farmers group, it needs the role of leader to push the activity of empowerment. The leader has a very important role to influence and motivate the farmers to achieve their goal together through the farmer groups. The aims of this research are to analysis the correlation between leadership with process of farmer groups empowerment, the correlation between the empowerment process with level of empowerment, and also the correlation between personal factor and environment factor with the empowerment process. The methods which is used in this research is survey which is supported by qualitative approach with in-depth interviews to the informants. The result of this research was processed by using Rank Spearman and Chi-Square. The research was conducted to the farmer groups Bina Sejahtera in Situ Udik Village, Cibungbulang Sub-District, Bogor and to the farmer groups Hurip in Cikarawang Village, Dramaga Sub-District, Bogor District. The result of the research shows a real positive correlation between the leadership with the empowerment process, while the empowerment process doesn't show a real positive correlation with the level of empowerment. Some personal factors show a real positive correlation with the level of empowerment.
\end{abstract}

Keywords: farmers empowerment, farmer group, leadership

\section{ABSTRAK}

Ketidakberdayaan petani disebabkan karena petani tidak cukup mampu untuk menggunakan peralatan produksi secara optimal. Ketidakberdayaan juga disebabkan oleh kurang kompetensinya petani dalam memasarkan produk pertaniannya. Melalui kelompok tani, pemerintah telah melakukan proses pengajaran yang potensial dan pemberdayaan untuk meningkatkan kualitas hidup petani. Dalam proses pemberdayaan kelompok tani ini, membutuhkan peran pemimpin untuk mendorong aktivitas pemberdayaan. Pemimpin memiliki peran yang penting untuk mempengaruhi dan memotivasi petani untuk mencapai tujuannya secara bersama-sama melalui kelompok tani. Tujuan penelitian ini. yaitu untuk menganalisis hubungan antara kepemimpinan dengan proses pemberdayaan kelompok tani, menganalisis hubungan antara proses pemberdayaan dengan tingkat pemberdayaan, juga menganalisis hubungan antara faktor pribadi dan faktor lingkungan dengan proses pemberdayaan. Metode yang digunakan adalah survey yang didukung pendekatan kualitatif dengan wawancara mendalam kepada narasumber. Hasil penelitian ini diolah menggunakan Rank Spearman dan Chi-Square. Penelitian ini dilakukan pada Kelompok Tani Bina Sejahtera di Desa Situ Udik, Kecamatan Cibungbulang, Bogor dan Kelompok Tani Hurip di Desa Cikarawang, Kecamatan Dramaga, Kabupaten Bogor. Hasil penelitian ini menunjukkan hubungan positif nyata antara kepemimpinan dengan proses pemberdayaan, sementara proses pemberdayaan tidak berhubungan positif nyata dengan tingkat pemberdayaan. Beberapa faktor pribadi menunjukkan hubungan positif nyata dengan tingkat pemberdayaan.

Kata kunci : kelompok tani, kepemimpinan, pemberdayaan petani

\section{PENDAHULUAN}

\section{Latar Belakang}

Indonesia merupakan negara agraris yang subur makmur sehingga tidak heran jika sebagian besar penduduk Indonesia bermatapencaharian sebagai petani. Besarnya kekayaan alam di Indonesia tidak menjamin bahwa petaninya juga berdaya. Kebanyakan petani hidup di dalam ketidakberdayaan baik tidak berdaya secara sosial maupun secara ekonomi. Berdasarkan data BPS pada bulan Maret 2013 mengemukakan bahwa jumlah penduduk miskin di pedesaan terutama yang bermata pencaharian sebagai petani mencapai 81.56 persen. Faktor lain yang menunjukkan ketidakberdayaan petani secara umum adalah dilihat dari pembangunan manusianya. Melihat posisi prestasi Indeks 
Pembangunan Manusia (IPM) yang tercantum pada jurnal nasional 20 Maret 2013, IPM Indonesia mengalami peningkatan dari peringkat 124 dari 187 Negara kini menjadi peringkat ke-121 dari 187 Negara (Dimyati 2013). Meskipun mengalami peningkatan, posisi ini dinilai masih rendah dan masih perlu perhatian khusus dari pemerintah Indonesia. Salah satu bentuk perhatian pemerintah Indonesia terhadap masalah IPM adalah dengan berfokus kepada pemberdayaan petani.

Pemberdayaan petani lebih efektif dilakukan melalui kelompok tani. Menurut Permentan Nomor 82 Tahun 2013 tentang kelompok tani dan gabungan kelompok tani mengungkapkan bahwa klasifikasi kemampuan kelompok tani dibagi ke dalam empat kategori yaitu: kelas pemula, kelas lanjut, kelas madya, dan kelas utama. Keempat kelas ini menunjukkan kemampuan yang dimiliki para petani tergolong kepada tingkatan kelas tersebut. Artinya tingkat keberdayaan yang dimiliki atas kegiatan pemberdayaan yang diberikan akan memberikan dampak terhadap tingkat kemampuan yang dimiliki anggota kelompok tani.

Berdasarkan data yang dimiliki oleh BKP5K Kabupaten Bogor, tingkat kemampuan kelompok tani di Kabupaten Bogor menunjukkan sebanyak 32 kelompok atau 1.27 persen kelompok tani berhasil mencapai tingkat kemampuan utama, sebanyak 322 kelompok atau 12.80 persen kelompok tani berhasil mencapai tingkat kemampuan madya, sebanyak 1 234 kelompok atau 49.06 persen kelompok tani berhasil mencapai tingkat kemampuan lanjut, dan sebanyak 297 kelompok atau 11.81 persen kelompok tani masih pada kemampuan pemula. Hal ini membuktikan bahwa kualitas kelompok tani di Kabupaten Bogor dinilai masih rendah sehingga petani perlu mengalami suatu proses pemberdayaan melalui pembelajaran untuk mengetahui kesempatan-kesempatan dalam memperbaiki hidupnya.

Pemberdayaan petani merupakan sebuah kegiatan yang melibatkan partisipasi dan kepemimpinan dari kelompok tani yang diberdayakan. Pemimpin yang memiliki dorongan kepemimpinan yang baik akan mampu mempengaruhi anggotanya untuk dapat terlibat dan berperan aktif dalam kegiatan pemberdayaan petani. Dinyatakan dalam Permentan Nomor 82 Tahun 2013 bahwa "pemberdayaan petani dapat dilakukan melalui kegiatan pelatihan dan penyuluhan dengan pendekatan kelompok tani”. Kelompok tani merupakan kumpulan petani/peternak/pekebun yang dibentuk atas dasar kesamaan kepentingan; kesamaan kondisi lingkungan sosial, ekonomi, dan sumberdaya; kesamaan komoditas; dan keakraban untuk meningkatkan dan mengembangkan usaha anggota (Kementrian Pertanian). Kelompok tani juga didefinisikan sebagai sebuah kelembagaan di tingkat petani yang dibentuk untuk mengorganisir para petani dalam berusahatani (Hermanto dan Swastika, 2011).

Kepemimpinan dibutuhkan dalam proses pemberdayaan karena memiliki pengaruh yang kuat terhadap anggotanya guna mencapai tujuan bersama Andrew dan Dubrin (2006) juga mengungkapkan bahwa kepemimpinan diartikan sebagai kekuatan yang dinamis dalam memotivasi dan mengkoordinasi anggota kelompoknya. Untuk itu, dukungan kepemimpinan dalam tercapainya mencapai tujuan sangat dibutuhkan baik oleh kelompok taninya maupun oleh anggota kelompok taninya. Kepemimpinan juga memiliki andil dalam mempengaruhi sukses tidaknya kegiatan pemberdayaan terhadap anggota kelompok tani.
Untuk itu, permasalahan umum yang akan dibahas dalam penelitian ini adalah sejauh mana peran pemimpin dalam efektivitas pemberdayaan petani pada kelompok tani Bina Sejahtera di Desa Situ Udik Kecamatan Cibungbulang Kabupaten Bogor dan kelompok tani Hurip di Desa Cikarawang Kecamatan Dramaga Kabupaten Bogor.

\section{Masalah Penelitian}

1. Sejauh mana hubungan kepemiminan dengan efektivitas program pemberdayaan petani melalui kelompok tani?

2. Sejauh mana hubungan antara pemberdayaan yang dilakukan dengan tingkat keberdayaan anggota kelompok tani?

3. Sejauh mana hubungan faktor lingkungan dan faktor personal dengan keberdayaan anggota kelompok tani

\section{Kegunaan Penelitian}

Penelitian ini diharapkan dapat memberikan kegunaan bagi banyak kalangan, di antaranya bagi akademisi, bagi penentu kebijakan, dan masyarakat dalam kegiatan pemberdayaan kelompok tani dan dalam melihat sejauh mana peranan pemimpin kelompok tani dalam mengayomi kelompok yang dipimpinnya. Penelitian ini juga diharapkan sebagai bahan pembelajaran bagi semua pemimpin, khususnya pemimpin kelompok tani.

\section{PENDEKATAN TEORITIS}

\section{Konsep Kepemimpinan}

Kepemimpinan sangat dibutuhkan dalam proses pemberdayaan masyarakat karena kepemimpinan memiliki pengaruh yang sangat kuat terhadap masyarakat guna mencapai kesejahteraan bersama (Mulyadi dan Rivai, 2012; Hessel dan Tangkilisan, 2007). Menurut Andrew dan Dubrin (2006) kepemimpinan didefinisikan sebagai kekuatan yang dinamis dalam memberikan motivasi dan koordinasi dalam rangka mencapai tujuan. Kepemimpinan timbul pada diri seorang pemimpin diakibatkan oleh tempaan dari pengalaman dirinya, namun kepemimpinan juga timbul akibat faktor genetik atau kemampuan yang dibawanya sejak lahir dan merupakan suatu kebutuhan yang muncul pada situasi tertentu (Hessel dan Tangkilisan, 2005).

Berdasarkan legitimasi yang diterima, kepemimpinan dibagi menjadi dua (Fadli, 2010; Tohani, 2012). Pertama kepemimpinan formal, yaitu kepemimpinan yang didapatkan berdasarkan legitimasi yang didapat dari pemerintah atau orgamisasi melalui surat pengangkatan. Kedua kepemimpinan informal, yaitu kepemimpinan yang didapat berdasarkan legitimasi yang diterima dari masyarakat. Kepemimpinan informal memiliki kedudukan yang lebih tinggi dibandingkan dengan masyarakat lainnya. Kepemimpinan diyakini sebagai orang atau figur yang strategis dalam menyampaikan ide-ide pembaharu bagi pembangunan di masyarakat karena kepemimpinan informal memiliki kedekatan emosional dan pengaruh yang cepat terhadap para pengikutnya (Tohani, 2012).

Fungsi diartikan sebagai sebuah jabatan atau pekerjaan yang melekat pada status seorang pemimpin. Fungsi kepemimpinan berhubungan langsung dengan keadaan 
kondisi sosial lingkungan di dalam kelompok (Mulyadi dan Rivai, 2012). Fungsi kepemimpinan merupakan sebuah keharusan untuk diwujudkan dalam interaksi sosial sebuah kelompok atau organisasi. Fungsi kepemimpinan dibagi ke dalam lima fungsi pokok kepemimpinan (Mulyadi dan Rivai, 2012), yaitu:

1. Fungsi intruksi. Komunikasi yang terjadi antara pemimpin dengan anggota di dalam sebuah organisasi merupakan komunikasi yang bersifat satu arah. Dalam komunikasi ini biasanya pemimpin dijadikan sebagai komunikator yang menentukan apa, bagaimana, bilamana, dan di mana perintah dikerjakan agar keputusan dapat diwujudkan secara efektif. Selain itu, pemimpin juga berkewajiban untuk memotivasi anggota sehingga mereka mau untuk dapat melaksanakan perintah.

2. Fungsi konsultasi. Komuniksi yang terjadi adalah komunikasi yang bersifat dua arah. Pemimpin memberikan keputusan yang kemudian anggota memberikan masukan untuk memperbaiki dan menyempurnakan keputusan yang telah ditetapkan untuk dilaksanakan. Dengan adanya komunikasi dua arah maka diharapkan kepemimpinan yang dijalankan dapat berlangsung efektif.

3. Fungsi partisipasi. Pemimpin berusaha mengaktifkan orang-orang yang dipimpinnya. Pemimpin tetap berada pada posisi sebagai fungsi pemimpin dan anggota berada pada posisi pelaksana.

4. Fungsi delegasi. Pemimpin memberikan atau melimpahkan wewenang untuk menetapkan keputusan, baik melalui persetujuan maupun tanpa persetujuan dar pemimpin. Fungsi ini didasarkan pada kepercayaan yang diberikan kepada seseorang dengan meyakini bahwa terdapat kesamaan prinsip, persepsi, dan aspirasi.

5. Fungsi pengendalian. Seorang pemimpin berfungsi sebagai orang yang dapat mengendalikan kelompok atau organisasinya. Pemimpin yang sukses adalah pemimpin yang dapat mengatur aktivitas kelompoknya sesuai dengan tujuan yang ingin dicapai bersama. Pengendalian dapat diwujudkan dalam bentuk kegiatan bimbingan, memberikan pengarahan, koordinasi dan pengawasan.

Pemimpin yang baik adalah pemimpin yang menjalankan peranan kepemimpinan dengan efektif. Kepemimpinan yang efektif ditunjukkan melalui peran-peran kepemimpinan (Arisunda dan Helmi, 2009; Andrew dan Dubrin, 2006), di antaranya:

1. Inspirasi. Pemimpin berperan sebagai seorang yang memberi suri tauladan agar bisa memberikan inspirasi bagi orang lain.

2. Persuasi. Pemimpin dapat mempersuasi orang lain dengan mengubah pikiran anggotanya.

3. Pengaruh. Pemimpin dapat mempengaruhi anggotanya agar dapat melaksanakan sesuatu yang positif.

4. Motivasi. Pemimpin dapat memberikan motivasi dengan mengajak anggota untuk bekerja lebih keras.

5. Kepribadian. Memiliki kepribadian yang baik, seperti pandai memuji, menghargai hasil karya orang lain, jujur, dan terbuka.
6. Pemimpin yang dapat memberikan informasi penting kepada anggotaya.

Merujuk pada Utama (2008) kepemimpinan berperan sebagai orang yang dapat mempengaruhi, mengarahkan, menggerakkan dan mengelola kelompok guna mencapai tujuan yang telah disepakati bersama. Keefektifan kepemimpinan erat kaitannya dengan keberlanjutan kelompok dalam mencapai tujuan bersama. Dalam melihat hubungan antara kepemimpinan dengan anggota kelompok tani, maka indikator yang dipakai adalah dengan melihat peran pemimpin kelompok tani, perilaku kepemimpinan, dan gaya kepemimpinan.

\section{Konsep Pemberdayaan}

\section{Ketidakberdayaan}

Ketidakberdayaan petani didefinisikan sebagai petani yang mengalami diskriminasi dan penilaian negatif serta interaksi negatif dari orang lain (Suharto, 1997 dalam Suharto, 2005). Penilaian diri yang negatif merupakan ketidakberdayaan diri yang disebabkan oleh penilaian negatif orang lain, sedangkan interaksi negatif dengan orang lain merupakan ketidakberdayaan yang bersumber dari pengalaman negatif dalam interaksi antara korban yang tertindas dengan mereka yang menindas. Penilaian diri dan interaksi yang negatif ini biasanya dapat menghambat peran orang-orang yang terdiskriminasi dalam lingkungan yang lebih luas.

Menurut Suharto (2005) bahwa kelompok lemah dan ketidakberdayaan yang dialaminya dapat dikategorikan menjadi tiga kategori. Pertama, kelompok lemah secara struktural, baik lemah secara kelas, gender maupun etnis. Kedua, kelompok lemah khusus, seperti manula, anak-anak dan remaja, penyandang cacat, gay dan lesbian, masyarakat terasing. Ketiga, kelompok lamah secara personal, yaitu mereka yang mengalami masalah pribadi dan/atau keluarga. Ketidakberdayaan tersebut menjadikan mereka kurang percaya diri dalam menonjolkan kemampuan yang dimiliki. Mengacu pada hasil penelitian yang dilakukan Agus (2009) mengungkapkan bahwa karakteristik petani yang belum berdaya di antaranya:

1. Memiliki pendidikan yang rendah

2. Bekerja sebagai buruh

3. Rendahnya kemampuan penyediaan dana

4. Rendahnya pengetahuan dalam pemanfaatan bahan baku yang tersedia

5. Pemasaran masih dalam lingkup lokal

6. Rendahnya kemampuan membuat perencanaan

7. Rendanya kemampuan dalam menjelaskan hal-hal yang merusak lingkungan.

\section{Keberdayaan}

Keberdayaan merupakan hasil dari sebuah proses kegiatan pemberdayaan yang kita sebut sebagai tujuan dari pemberdayaan masyarakat. Keberdayaan didefinisikan sebagai masyarakat yang mampu secara ekonomi, mampu dalam mengakses manfaat fasilitas dan mempunyai kemampuan kultural dan politis (Suharto, 2005). Petani yang berdaya adalah petani yang memiliki kekuatan atau kemampuan dalam hal: 
1. Memenuhi kebutuhan dasarnya sehingga mereka memiliki kebebasan (freedom), artinya mereka bebas untuk mengungkapkan pendapat, bebas dari kelaparan, bebas dari kebodohan, dan bebas dari kesakitan;

2. Menjangkau sumber-sumber produktif yang memungkinkan mereka dapat meningkatkan pendapatannya dan memperoleh barang-barang dan jasa-jasa yang mereka perlukan;

3. Berpartisipasi dalam proses pembangunan dan keputusan yang mempengaruhi mereka.

Petani berdaya merupakan petani yang memiliki pengetahuan, keterampilan, dan tindakan terhadap potensi yang dimilikinya. Untuk mencapai tingkat keberdayaan, maka petani harus mengikuti kegiatan-kegiatan pemberdayaan melalui beberapa hal, yaitu pendekatan terhadap masyarakat dan penyuluhan agar dapat meningkatkan tingkat pengetahuan, kemampuan, dan kreativitas. Mengacu pada Sumodiningrat (1999), proses menuju keberdayaan petani dilihat dari beberapa sudut pandang di antaranya: a. menciptakan iklim atau suasana yang memungkinkan petani berkembang; $b$. peningkatkan kemampuan petani dalam membangun melalui bantuan dana, pelatihan, pembangunan sarana, prasarana baik fisik maupun sosial, dan pengembangan kelembagaan daerah; c. perlindungan dengan keberpihakan pada petani yang lemah; d. menciptakan kemitraan yang saling menguntungkan. Adapun menurut Utami (2006) proses pemberdayaan dilihat dari tiga aspek yang disajikan pada Tabel 2. Ketiga aspek perilaku pada Tabel 2 digunakan dalam materi pokok penyuluhan petani tentang (a) kewirausahaan yang meliputi keinovatifan, inisiatif, pengelolaan resiko, dan daya saing; (b) kemandirian yang meliputi: permodalan, proses produksi, kerjasama, dan pemasaran. Dari dua materi pokok tersebut yang akan dijadikan sebagai indikator untuk mengukur tingkat kemampuan kognitif, afektif dan psikomotorik petani. Indikator yang digunakan adalah pengelolaan resiko, permodalan, dan pemasaran.

Petani yang berdaya merupakan wujud advokasi dari berbagai pihak. Salah satu yang menciptakan advokasi bagi petani adalah pemerintah, local community organization, dan lembaga swadaya masyarakat (Pratama, 2013). Pemerintah berkewajiban membantu kelompok tani melalui bantuan barang berupa pupuk, obat-obatan, teknologi pertanian dan bantuan materi berupa pengetahuan dan pinjaman modal usaha agar tujuan dari pemberdayaan dapat tercapai. Adapun local community organization berperan sebagai penampung ide petani, mengumpulkan petani untuk bermusyawarah, dan memberikan jalan keluar dari setiap permasalahan yang dihadapi petani.

Kegiatan pemberdayaan kelompok tani dipengaruhi oleh dua faktor pendukung, di antaranya adalah faktor personal dan faktor lingkungan. Faktor personal berpengaruh terhadap kendali dan alasan keikutsertaan petani dalam kegiatan pemerdayaan. Faktor personal meliputi usia, tingkat pendidikan, luas lahan, status kepemilikan lahan, dan pengalaman usaha tani (Cepriadi dan Yulida, 2012). Faktor personal dijelaskan lebih rinci sebagai berikut.

(1) Usia. Usia merupakan salah satu faktor yang dapat mempengaruhi petani untuk membuat keputusan dalam penerapan teknologi dan inovasi baru dalam kegiatan pengembangan usaha tani. Hasil penelitiannya Cepriadi dan Yulida (2012) membuktikan bahwa secara keseluruhan usaha tani dikelola oleh petani pada usia produktif yaitu usia yang berkisar 21-50 tahun. Sedangkan usia dalam analisis demografi menurut BKKBN (1994) usia dibagi ke dalam tiga kelompok, yaitu: (a) kelompok usia muda, di bawah 15 tahun; (b) kelompok usia produktif, usia 15-64 tahun; dan (c) kelompok umur tua, usia 65 ke atas.

(2) Tingkat pendidikan berpengaruh terhadap pola pikir petani dalam mengelola usaha tani. Tingkatan pendidikan ditentukan oleh tingkat pendidikan secara formal, meskipun sebenarnya pendidikan non-formal juga merupakan sumbangsih dalam membentuk pola pikir agar petani lebih berdaya di bidang pegetahuan, sikap, dan keterampilan.

(3) Luas dan status kepemilikan lahan merupakan hal mendasar dalam usaha tani. Menurut Dinas Pertanian Pangan dan Holtikultura Kabupaten Pelalawan (2009) dalam Cepriadi dan Yulida (2012) luas lahan minimal yang harus dimiliki adalah 0,2 ha atau $2000 \mathrm{~m} 2$ yang letaknya dengan sumber air yang cukup dan dapat dijangkau oleh petugas penyuluh. Status Kepemilikan lahan petani yang digunakan untuk usaha tani terdiri dari beberapa istilah yaitu lahan milik pribadi, lahan pinjaman, dan lahan hasil sewa.

(4) Pengalaman usaha tani berpengaruh terhadap keberhasilan usaha tani karena mampu memberikan pelajaran kepada petani dalam menghadapi resiko dan mengetahui cara mengatasi berbagai masalah.

Faktor dukungan lain untuk meningkatkan semangat dalam kegiatan pemberdayaan menurut Utama (2008) adalah dengan dukungan lingkungan. Indikator dukungan lingkungan yang digunakan dalam penelitian terhadap kelompok tani adalah akses lahan, ketersediaan sarana produksi, kemudahan memasarkan hasil, dan potensi pengembangan usaha.

\section{Penyuluhan}

Menurut UU Nomor 16 Tahun 2006 tentang Sistem Penyuluhan Pertanian, Perikanan, dan Kehutanan, yang dimaksud dengan penyuluhan adalah sebuah proses pembelajaran bagi pelaku utama serta pelaku usaha agar mereka mau dan mampu menolong dan mengorganisasikan dirinya dalam mengakses informasi pasar, teknologi, permodalan, dan sumber daya lainnya, sebagai upaya untuk meningkatkan produktivitas efisiensi usaha, pendapatan, dan kesejanteraan, serta meningkatkan kesadaran dalam pelestarian fungsi lingkungan hidup. Penyuluhan merupakan suatu sistem pendidikan di luar sekolah untuk petani di pedesaan agar dapat meningkatkan pengetahuan, keterampilan dan sikap mentalnya menjadi lebih produktif sehingga mampu meningkatkan penghasilan keluarga (Setiana, 2005). Penyuluh dibagi ke dalam tiga golongan, yaitu penyuluh pegawai negeri sipil, penyuluh swasta, dan penyuluh swadaya. Penyuluh pegawai negeri sipil disebut sebagai penyuluh PNS, diberi tugas, wewenang, tanggung jawab, dan hak secara penuh untuk melakukan kegiatan penyuluhan oleh pejabat yang berwenang pada satuan organisasi lingkup pertanian. Penyuluh swasta merupakan penyuluh yang berasal dari dunia usaha yang mempunyai kompetensi dalam bidang penyuluhan. Sedangkan penyuluhan swadaya merupakan pelaku utama yang berhasil dalam usahanya dan masyarakat lainnya yang mempunyai kesadaran untuk menjadi penyuluh.

Kegiatan penyuluhan menggunakan materi sebagai bahan penyuluhan untuk disampaikan kepada subyek penyuluhan 
berupa informasi, teknologi, rekayasa sosial, manajemen, ekonomi, hukum, dan kelestarian lingkungan. Penyuluhan diselenggarakan berasaskan demokrasi, manfaat kesetaraan, keterpaduan, keseimbangan, keterbukaan, kerja sama, partisipatif, kemitraan, keberlanjutan, berkeadilan, pemerataan, dan bertanggung gugat (UU No.16 Tahun 2006). Fungsi dari sistem penyuluhan adalah:

1. Memfasilitasi proses pembelajaran subyek penyuluhan;

2. Mengupayakan kemudahan akses subyek penyuluhan kepada sumber informasi, teknologi, dan sumber daya lainnya agar mereka dapat mengembangkan usahanya;

3. Meningkatkan kemampuan kepemimpinan, manajerial, dan kewirausahaan pelaku utama dan pelaku usaha;

4. Membantu subyek penyuluhan dalam menumbuhkembangkan organisasinya menjadi organisasi ekonomi yang berdaya saing tinggi, produktif, menerapkan tata kelola berusaha yang baik, dan berkelanjutan;

5. Membantu menganalisis dan memecahkan masalah serta merespon peluang dan tantangan yang dihadapi subyek penyuluhan dalam mengelola usaha;

6. Menumbuhkan kesadaran pelaku utama dan pelaku usaha terhadap kelestarian fungsi lingkungan; dan

7. Melembagakan nilai-nilai budaya pembangunan pertanian, perikanan, dan kehutanan yang maju dan modern bagi pelaku utama secara berkelanjutan.

Fungsi penyuluhan menurut Setiana (2005) adalah untuk menjembatani kesenjangan antara praktik yang biasa dijalankan oleh para petani dengan pengetahuan dan teknologi yang selalu berkembang menjadi kebutuhan petani. Penyuluh dengan para penyuluhnya merupakan penghubung yang sifatnya dua arah (two way traffic) antara: pengetahuan yang dibutuhkan petani dan pengalaman yang biasa dilakukan oleh petani; pengalaman baru yang terjadi pada pihak para ahli dan kondisi yang nyata dialami petani.

Mengacu pada UU Nomor 16 Tahun 2006, tujuan dari sistem penyuluhan sendiri adalah meliputi pengembangan sumber daya manusia dan peningkatan modal sosial, yaitu sebagai berikut.

1. Memperkuat pengembangan pertanian yang maju dan modern dalam sistem pembangunan yang berkelanjutan;

2. Memberdayakan subyek penyuluhan untuk meningkatkan keemampuan melalui penciptaan iklim usaha yang kondusif, penumbuhan motivasi, pengembangan potensi, pemberian peluang, peningkatan kesadaran, dan pendampingan serta fasilitas;

3. Memberikan kepastian hukum bagi terselenggaranya penyuluhan yang produktif, efektif, efisien, terdesentralisasi, partisipatif, terbuka, berswadaya, bermitra sejajar, kesetaraan gender, berwawasan luas ke depan, berwawasan lingkungan, dan bertanggung gugat yang dapat menjamin terlaksananya pembangunan pertanian;

4. Memberikan perlindungan, keadilan, dan kepastian hukum bagi subyek penyuluhan untuk mendapatkan pelayanan penyuluhan serta bagi penyuluh dalam melaksanakan penyuluhan; dan
5. Mengembangkan sumber daya manusia, yang maju dan sejahtera, sebagai pelaku dan sasaran utama pembangunan pertanian.

Setiana (2005) mengungkapkan bahwa tujuan dari penyuluhan pertanian jangka panjang adalah terjadinya peningkatan taraf hidup masyarakat. Hal ini dapat dicapai apabila para petani telah melakukan hal-hal sebagai berikut.

1. Better farming, mau dan mampu mengubah cara-cara usaha taninya dengan cara-cara yang lebih baik.

2. Better business, berusaha yang lebih menguntungkan, mau dan mampu menjauhi para pengijon, lintah darat, dan melakukan teknik pemasaran yang benar.

3. Better living, hidup lebih baik dengan mampu menghemat, tidak berfoya-foya dan setelah panen, petani dapat menabung bekerja sama memperbaiki hygiene lingkungan dan mampu mencari alternatif lain dalam usaha.

Penyuluh memiliki peranan penting dalam melakukan pemberdayaan masyarakat petani melalui kelompok tani. Fatchiya (2010) dalam penelitiannya yang berjudul "Pola Pengembangan Kapasitas Pembudidaya Ikan Kolam Air Tawar di Provinsi Jawa Barat" mengidentifikasi peranan penyuluh dari kinerja penyuluhnya. Kinerja penyuluh dalam mengembangkan anggota kelompok tani sebagai pelaku utama dan pelaku usaha berdasarkan hasil penelitian Fatchiya (2010) adalah sebagai berikut.

1. Kinerja penyuluh dalam pengembangan kelompok terkait dengan kegiatan penyuluhan yang meliputi jadwal penyuluhan dan frekuensi penyuluhan.

2. Kinerja penyuluh dalam identifikasi masalah dan penyusunan rencana program melalui menetapkan materi, menyiapkan tempat, menentukan waktu, menentukan peserta, maupun penyediaan biaya.

3. Kinerja penyuluhan dalam proses pembelajaran merupakan suatu proses komunikasi yang sifatnya dua arah atau timbal balik, yaitu penyuluh memberi kesempatan kepada partisipan untuk mengemukakan pertanyaan, pendapat/usulan, dan sebaliknya penyuluh bertanya atau meminta pendapat dari partisipan.

Kinerja penyuluh dalam menjalin jejaring merupakan upaya penyuluh dalam menjalin kerjasama dengan lembagalembaga yang terkait dengan usahanya, baik dengan perbankan sebagai sumber modal usaha, pemasaran, penelitian, maupun lembaga penyedia input produksi. Di dalam proses pemberdayaan Tampubolon (2006) mengelompokkannya menjadi dua, yaitu pendampingan dan tingkat partisipasi.

\section{Partisipasi}

Partisipasi adalah keterlibatan seseorang dalam proses pembangunan yang didorong oleh maksud dan tujuan program pemberdayaan yang diikuti (Sutomo, 2012). Partispasi didasarkan kepada kebutuhan dan imbalan yang diterima. Diperlukan kaji tindak permasalahan yang dihadapi petani untuk menentukan kebutuhan tersebut. Fetterman dan Wandersman (2005), mengungkapkan sepuluh prinsip evaluasi pemberdayaan, di antaranya:

1. Prinsip kemajuan (improvement) ditekankan pada 
tiga peningkatan yaitu peningkatan nilai-nilai dalam lingkungan masyarakat, peningkatan secara kuantitatif yang dilihat berdasarkan jumlah, dan peningkatan kualitatif yang didasarkan pada proses dan hasil.

2. Prinsip kepemilikan komunitas (community ownership) menekankan pada kepemilikan komunitas, yaitu masyarakat memiliki hak untuk ikut berperan dan menentukan keputusan terhadap apa yang mempengaruhi terhadap dirinya sendiri. Masyarakat merupakan agen pembaharu untuk dapat memperbaiki dirinya sendiri ketika mereka dilibatkan dalam proses pemberdayaan. Program pemberdayaan yang dibuat merupakan milik mereka dan harus dijaga oleh mereka sehingga mereka bertanggung jawab terhadap keberhasilan atau kegagalan pemberdayaan tersebut.

3. Prinsip inklusif juga menekankan pada partisipasi langsung dalam pengambilan keputusan. Masyarakat diikutsertakan dalam berbagai proses mulai dari perencanaan sampai pada tahap evaluasi akhir. Masyarakat dituntut untuk menjadi iklusif oleh karena keputusan individu dibuat menjadi keputusan kelompok, karena hal yang demikian merupakan sebuah kunci keberhasilan pemberdayaan masyarakat, artinya keputusan yang dibuat berdasarkan hasil musyawarah. Tanpa inklusif maka evaluasi pemberdayaan yang dilakukan akan menjadi sia-sia mengakibatkan komunikasi menjadi semakin buruk, kontra produktif terhadap program pemberdayaan, perilaku rusak, dan akan menurunkan sumberdaya manusia.

4. Prinsip demokrasi, partisipasi melibatkan seluruh pemangku kepentingan, karena berkeyakinan bahwa pemangku kepentingan memiliki kapasitas yang tinggi terhadap penyampaian informasi untuk dapat menggerakkan masyarakat yang diberdayakan. Musyawarah dan kolaborasi menjadi sebuah hal yang sangat penting dalam memaksimalkan penggunaan keterampilan dan pengetahuan pada masyarakat. Dalam prinsip ini menekankan pada transparansi dengan kejelasan, keterbukaan dalam pembuatan perencanaan program yang akan dilaksanakan untuk dapat meningkatkan kepercayaan di antara para pemangku kepentingan.

5. Prinsip keadilan sosial, evaluasi pemberdayaan menggunakan prinsip keadilan sosial bertujuan untuk meningkatkan kondisi sosial masyarakat dalam upaya meningkatkan kinerja para pemangku kepentingan.

6. Prinsip pengetahuan komunitas (community knowledge) juga digunakan untuk bahan evaluasi pemberdayaan didasarkan pada komunitas itu sendiri. Masyarakat dalam komunitas tersebut dipercaya bahwa mereka mempunyai keahlian dan pengetahuan tentang diri mereka sendiri untuk dapat memberdayakan diri mereka dan mengidentifikasi mengenai kebutuhan mereka sendiri.

7. Prinsip berdasarkan bukti strategis (evidence based strategi), yaitu keberdayaan dilihat dari besarnya pemangku kepentingan yang terlibat yang ditunjukkan berdasarkan kenyataan yang ada.

8. Peningkatan kapasitas ditunjukkan dengan tingginnya kepemahaman mengenai pentingnya kebersamaan dalam mengelola suatu sumber daya yang dapat dimanfaatkan secara bersama-sama.

9. Prinsip pembelajaran organisasi, yaitu mendorong meningkatkan pengetahuan struktur organisasi dalam proses berfikir, melakukan perbaikan yang terusmenerus, menjadi penyelidik untuk dapat mencari jalan keluar dari setiap permasalahan yang dihadapi.

10. Prinsip akuntabilitas, yaitu dengan mengarahkan untuk bertanggung jawab baik kepada dirinya maupun publik atas konsekuensi dari tindakan yang telah dilakukan.

11. Mengacu kepada Korten (1987) bahwa partisipasi masyarakat meliputi tiga dimensi yaitu siapa, apa, dan bagaimana. Mengidentifikasi siapa adalah untuk melihat siapa yang berpartisipasi, apakah seluruh lapisan masyarakat atau hanya lapisan-lapisan tertentu saja. Identifikasi terhadap apa yaitu partisipasi yang dilihat dalam bentuk keterlibatan dalam pengambilan keputusan, keterlibatan dalam pelaksanaan, dan menikmati hasil. Identifikasi terhadap aspek bagaimana yaitu partisipasi yang dilihat dalam bentuk paksaan atau sukarela, partisipasi secara terus-menerus atau sewaktuwaktu. Untuk itu, bentuk partisipasi yang ideal adalah partisipasi yang melibatkan seluruh lapisan masyarakat dalam menyumbangkan ide, perubahan, dan partisipasi dalam proses pengambilan keputusan.

\section{Konsep Kelompok Tani}

Kelompok tani merupakan sebuah kelembagaan ditingkat petani yang dibentuk untuk mengorganisir para petani dalam berusaha tani (Hermanto dan Swastika, 2011). Kelompok tani juga diatur dalam Peraturan Menteri Pertanian Nomor 82 Tahun 2013 Tentang Pedoman Pembinaan Kelompok Tani dan Gabungan Kelompok Tani yang mendefinisikan bahwa "kelompok tani adalah kumpulan petani/peternak/pekebun yang dibentuk atas dasar kesamaan kepentingan, kesamaan kondisi lingkungan sosial, ekonomi, dan sumberdaya, kesamaan komoditas, dan keakraban untuk meningkatkan dan mengembangkan usaha anggota". Dalam kelompok tani terdapat anggota kelompok tani yang disebut sebagai pelaku utama dan pelaku usaha. Pelaku utama adalah petani yang melakukan usaha tani dibidang pangan, holtikultura, perkebunan, dan/ atau peternakan. Sedangkan pelaku usaha adalah setiap orang yang melakukan usaha agar mereka mau dan mampu menolong dan mengorganisasikan dirinya dalam mengakses informasi pasar, teknologi, permodalan, dan sumber daya lainnya untuk dapat meningkatkan produktivitas, efisiensi usaha, pendapatan, dan kesejahteraan, serta meningkatkan kesadaran dalam pelestarian lingkungan hidup.

Berdasarkan hasil penelitian Fatchiya (2010) kelompok mempunyai peranan sebagai koordinator pemasaran. Pembeli yang berminat terhadap hasil pertanian tidak perlu repot untuk menemui petani kepada tiap-tiap individu yang membudidayakan hasil pertanian yang sama, tetapi dapat berkunjung langsung kepada kelompoknya sebagai pemasar dari hasil budi daya anggota kelompoknya. Kelompok juga mempunyai fungsi sebagai tempat pembinaan bagi anggota kelompok tani. Pembinaan melalui kelompok memudahkan penyuluh menyelenggarakan kegiatan penyuluhan dikarenakan kelompok memiliki kegiatan budi daya yang sama, terjadi proses belajar bersama, dan adanya tanggung jawab bersama atas program bantuan yang diberikan. Fungsi-fungsi kelompok tani juga diatur dalam Permentan No. 82 Tahun 2013 yaitu:

1. Kelas belajar, yaitu kelompok tani sebagai wadah 
belajar mengajar bagi anggota guna meningkatkan pengetahuan, keterampilan dan sikap agar tumbuh dan berkembang menjadi usaha tani yang mandiri sehingga dapat meningkatkan produktivitas, pendapatan serta kehidupan yang lebih baik;

2. Wahana Kerjasama: kelompok tani merupakan tempat untuk memperkuat kerjasama baik di antara sesama petani dalam poktan dan antar poktan maupun dengan pihak lain. Melalui kerjasama tersebut diharapkan dapat membuat usahatani lebih efisien dan lebih mampu menghadapi ancaman, tantangan, hambatan, gangguan serta lebih menguntungkan;

3. Unit Produksi: Usahatani yang dilaksanakan oleh masing-masing anggota poktan secara keseluruhan harus dipandang sebagai satu kesatuan usaha yang dapat dikembangkan untuk mencapai skala ekonomis usaha, dengan menjaga kuantitas, kualitas maupun kontinuitas.

4. Kelompok tani ditumbuhkembangkan dari, oleh, dan untuk mereka dengan jumlah berkisar 20 sampai 25 orang petani atau disesuaikan dengan kondisi lingkungan masyarakat sekitarnya (Menteri Pertanian). Kepengurusan anggota kelompok tani sekurangkurangnya terdiri dari ketua, sekretaris, bendahara, dan seksi-seksi sesuai dengan kebutuhan. Sebagai penentu keberlanjutan dari penumbuhan kelompok tani maka harus dibentuk rencana kerja kelompok. Kemudian, dalam meningkatkan kemampuan petani anggota kelompok tani dalam pengembangan agribisnis (Permentan No. 82 Tahun 2013), maka:

5. Menciptakan iklim usaha yang kondusif agar petani mampu untuk membentuk dan menumbuhkembangkan kelompoknya secara partisipatif;

6. Menumbuhkembangkan kreatifitas dan prakarsa anggota kelompok tani untuk memanfaatkan setiap peluang usaha, informasi, dan akses permodalan yang tersedia;

7. Membantu memperlancar proses dan mengidentifikasi kebutuhan dan masalah serta menyusun rencana dan memecahkan masalah yang dihadapi dalam usaha taninya;

8. Meningkatkan kemampuan dalam menganalisis potensi pasar dan peluang usaha serta menganalisis potensi wilayah dan sumber daya yang dimiliki untuk mengembangkan komoditi yang dikembangkan/ diusahakan guna memberikan keuntungan usaha yang optimal;

9. Meningkatkan kemampuan anggota untuk dapat mengelola usaha tani secara komersial, berkelanjutan, dan akrab lingkungan;

10. Meningkatkan kemampuan anggota dalam menganalisis potensi usaha masing-masing anggota untuk dijadikan satu unit usaha yang menjamin permintaan pasar yang dilihat dari kuantitas, kualitas, serta kontinuitas.

11. Mengembangkan kemampuan anggota untuk menciptakan teknologi yang spesifik lokalitas;

12. Mendorong dan mengadvokasi agar para petani mau dan mampu melaksanakan kegiatan simpan-pinjam guna memfasilitasi pengembangan modal usaha kelompok tani.

\section{Kerangka Pemikiran}

Keberdayaan masyarakat dilihat dari perubahan tingkatan yang rendah menjadi tingkatan yang lebih tinggi. Tingkat keberdayaan meliputi tingkat pengetahuan, sikap, dan keterampilan. Tingkat keberdayaan ini dipengaruhi oleh proses pemberdayaan, yang mana di dalam proses pemberdayaan terdapat teknik pendampingan dan tingkat partisipasi. Proses pemberdayaan ini diharapkan mampu menjadi jembatan agar petani mampu meningkatkan tingkat keberdayaan mereka. Agar mampu menggerakkan proses intensitas pemberdayaan ini, maka dukungan kepemimpinan sangat dibutuhkan. Dukungan kepemimpinan tersebut meliputi peran kepemimpinan, perilaku kepemimpinan, dan gaya kepemimpinan. Selain kepemimpinan, terdapat dua faktor yang diduga mempunyai hubungan tidak langsung dengan tingkat keberdayaan petani. Faktorfaktor tersebut di antaranya adalah faktor lingkungan dan faktor personal. Faktor lingkungan meliputi akses lahan, ketersediaan saprodi, kemudahan pemasaran hasil, potensi pengembangan usaha, sedangkan faktor personal meliputi usia, tingkat pendidikan, status kepemilikan lahan, luas lahan, dan pengalaman dalam usaha tani.

\section{Hipotesis Penelitian}

- H1 :Terdapat hubungan nyata antara kepemimpinan (peran kepemimpinan, perilaku kepemimpinan, gaya kepemimpinan) dengan proses pemberdayaan (pendampingan, tingkat partisipasi)

- $\mathrm{H} 2$ :Terdapat hubungan antara proses pemberdayaan (pendampingan, tingkat partisipasi) dengan tingkat keberdayaan

- $\mathrm{H} 3 \quad$ :Terdapat hubungan nyata antara faktor personal (usia, tingkat pendidikan, status kepemilikan lahan, pengalaman usaha tani) dengan proses pemberdayaan (pendampingan, tingkat partisipasi)

- $\mathrm{H} 4$ :Terdapatn hubungan nyata antara faktor lingkungan (akses lahan, ketersediaan saprodi, kemudahan pemasaran hasil, potensi pengembangan usaha) dengan proses pemberdayaan (pendampingan, tingkat partisipasi)

\section{PENDEKATAN LAPANGAN}

\section{Lokasi dan Waktu Penelitian}

Penelitian ini dilakukan di dua lokasi, yaitu di Desa Situ Udik, Kecamatan Cibungbulang, Kabupaten Bogor dan di Desa Cikarawang, Kecamatan Dramaga, Kabupaten Bogor. Kedua lokasi ini memiliki kelompok tani yang masing-masing nama keompok taninya adalah kelompok tani Bina Sejahtera dan kelompok tani Hurip. Pemilihan kelompok tani pada kedua desa ini berdasarkan informasi dari Badan Ketahanan Pangan dan Pelaksana Penyuluhan Pertanian, Perikanan dan Kehutanan (BKP5K) Kabupaten Bogor bahwa kelompok tani Hurip merupakan kelompok tani yang sering dikunjungi untuk lokasi percontohan baik itu kunjungan dari pemerintah maupun dari kalangan akademisi sebagai lokasi penelitian dan sasaran pemberdayaan, sehingga penulis tertarik melihat peranan kepemimpinan pada kelompok tani tersebut, sedangkan kelompok tani Bina Sejahtera merupakan salah satu kelompok tani berprestasi di tingkat Jawa Barat. 


\section{Teknik Pengumpulan Data}

Jenis data yang dikumpulkan dalam penelitian ini adalah data primer dan data sekunder. Data primer didapatkan langsung di lapangan dengan cara observasi, kuesioner, serta wawancara mendalam yang dilakukan langsung kepada responden maupun informan. Data sekunder diperoleh baik dari dokumen-dokumen tertulis di BKP5K Kabupaten Bogor, kelompok tani Bina Sejahtera dan kelompok tani Hurip. Data sekunder berupa dokumendokumen yang terkait dengan penelitian ini, seperti dokumen perkembangan kelompok tani dari tahun ke tahun, perubahan kondisi kelompok tani berdasarkan tingkat kemampuan kelompok tani dan kegiatan penyuluhan yang diberikan untuk meningkatkan tingkat kemampuan kelompok tani. Data sekunder juga diperoleh melalui berbagai literatur yang berkaitan dengan permasalahan yang akan dibahas pada penelitian ini, yaitu: buku, laporan hasil penelitian, artikel, dan sebagainya.

\section{Teknik Pengolahan dan Analisis Data}

Data yang diperoleh dari hasil penelitian berupa data kualitatif dan data kuantitatif. Semua data kuantitatif yang diperoleh dimasukkan ke dalam Microsoft Excel 2007 serta diolah menggunakan Program SPSS 20.0. for Windows. Pada pengujian hipotesis, dilakukan dengan menggunakan statistik non-parametik Uji Korelasi Rank Spearman untuk melihat hubungan variabel yang diukur dengan skala ordinal dan Uji Korelasi Chi Square untuk melihat hubungan variabel yang diukur dengan skala nominal. Pada kualitatif, semua data dianalisis melalui tiga tahap, yaitu reduksi data, penyajian, dan penarikan kesimpulan.

\section{GAMBARAN UMUM LOKASI PENELITIAN}

Penelitian dilaksanakan di Desa Situ Udik Kecamatan Cibungbulang Kabupaten Bogor pada kelompok tani Bina Sejahtera dan di Desa Cikarawang Kecamatan Dramaga Kabupaten Bogor pada kelompok tani Hurip. Desa Situ Udik adalah salah satu Desa yang berada di Kecamatan Cibungbulang Kabupaten Bogor, tepatnya di Kecamatan Cibungbulang bagian selatan yang berbatasan langsung dengan Kecamatan Pamijahan dan Kecamatan Leuwiliang. Desa Situ Udik memiliki jumlah penduduk sebanyak 14 500 jiwa pada tahun 2013.

Desa Situ Udik memiliki luas wilayah 370 ha dan dibagi menjadi tiga Dusun, 12 RW dan 43 RT. Batas-batas Desa Situ Udik adalah pada sebelah utara berbatasan dengan Desa Situ Ilir Kecamatan Cibungbulang; Sebelah timur berbatasan dengan Desa Cimayang dan Desa Gunung Menyan Kecamatan Pamijahan; sebelah selatan berbatasan dengan Desa Pasarean Kecamatan Pamijahan; dan sebelah barat berbatasan dengan Desa Karacak dan Desa Karya Sari Kecamatan Leuwiliang. Adapun Desa Cikarawang merupakan Desa yang berada di Kecamatan Dramaga Kabupaten Bogor dengan luas wilayah 226.56 ha. Desa Cikarawang memiliki jumlah penduduk sebanyak 8227 jiwa yang terdiri dari 4199 laki-laki dan 4028 perempuan. Desa Cikarawang terdiri dari 3 Dusun, 7 RW, dan 32 RT dengan batasan-batasan sebagai berikut. Disebelah utara berbatasan dengan Sungai Cisadane; sebelah timur berbatasan dengan Kelurahan Situ Gede; sebelah selatan berbatasan dengan Sungai Ciapus; dan sebelah barat berbatasan dengan Sungai Cisadane.

\section{Profil Kelompok Tani Bina Sejahtera}

Kelompok Tani Bina Sejahtera berdiri sejak tahun 2008 dengan komoditi utama adalah perikanan air tawar khususnya ikan mas, lele, nila, bawal, dan patin. Pada tahun 2008 kelompok tani Bina Sejahtera memulai kegiatan sebagai pembudidaya ikan, yaitu pertemuan rutin kelompok, kursus tani, demplot, sekolah lapang pengelolaan tanaman terpadu (SL-PTT), dan pelatihan budi daya bawal dan lele terhadap anggota, serta pelatihan budi daya nila terhadap pemuda Agri Mandiri. Awalnya kelompok tani ini memiliki anggota sebanyak 40 orang secara administrasi, namun pada kenyataannya anggota kelompok tani Bina Sejahtera yang ada hanya sebanyak 28 orang. Hal ini disebabkan banyak anggota kelompok tani yang sibuk dengan pekerjaannya masing-masing dan beberapa anggota yang sudah sepuh bahkan ada yang sudah meninggal.

Kelompok Tani Bina Sejahtera merupakan kelompok tani yang sudah berdiri pada tingkatan kelas madya sejak tahun 2010. Meskipun berkiprah pada budi daya ikan air tawar, pada kenyataannya kondisi wilayah anggota kelompok tani sebagian besar merupakan lahan pertanian dengan hasil pertanian berupa padi, palawija, dan sayuran. Luas lahan pesawahan atau irigasi secara keseluruhan adalah 25 ha, lahan darat seluas 5 ha dan lahan kolam adalah seluas 20 ha.

Latar belakang pembentukan kelompok tani budi daya ikan ini adalah melihat pada prospek agribisnis perikanan air tawar (mas, lele, nila, gurame, bawal, dan patin) di Jawa Barat menjanjikan keuntungan baik dari segi teknis, ekonomis, dan sosial. Dari segi teknis, usaha perikanan air tawar sudah cukup berkembang dan mudah menyesuaikan dengan lingkungan. Dari segi ekonomis memiliki pangsa pasar cukup besar baik unuk pemenuhan kebutuhan dalam negeri maupun untuk ekspor. Dari segi sosial, membudidayakan jenis ikan gurame, lele, nila, gurame, sudah memasyarakat dikalangan pembudidaya ikan dan dagingnya digemari masyarakat. Anggota berkomitmen tinggi untuk menjalankan dan mengembangkan usaha dengan sungguh-sungguh, sehingga tim pembudidaya bertekad untuk dapat saling melengkapi, solid, amanah, dan bertanggung jawab.

Kelompok tani Bina Sejahtera juga memiliki visi dan misi dalam menjalankan kegiatan kelompoknya. Visi dari kelompok tani Bina Sejahtera adalah "Terwujudnya Pembudidaya Ikan menjadi Pelaku Utama dan Pelaku Usaha, Mandiri, berkualitas dan Sejahtera", sedangkan misinya yaitu:

1. Menjadikan sektor perikanan sebagai prime mover, yakni penggerak utama ekonomi masyarakat (ekonomi berbasis perikanan)

2. Menghasilkan benih yang memiliki brand quality

3. Mencetak pengusaha-pengusaha muda yang mampu bersaing secara profesional

4. Ikut berpartisipasi meningkatkan Indeks Pembangunan Manusia(IPM), khususnya pada dimensi pembangunan ekonomi kerakyatan

Kelompok tani Bina Sejahtera memiliki aset kelompok yang dapat digunakan guna mendukung pelaksanaan kegiatan kelompok, antara lain sebagai berikut. 
Tabel 1. Rincian Aset Milik Kelompok Tani Bina Sejahtera

\begin{tabular}{lll}
\hline No & Jenis Aset & Jumlah \\
\hline 1 & Tanah & - \\
2 & Bangunan/Saung Sekretariat (unit) & 2 \\
3 & Alat-alat perikanan (paket) & 1 \\
4 & Demplot (paket) & 1 \\
5 & Indukan Ikan $(\mathrm{kg})$ & 200 \\
\hline
\end{tabular}

Sumber: Profil kelompok tani Bina Sejahtera (2014)

Hasil produksi yang telah diusahakan dengan menggunakan aset tersebut hingga sampai saat ini adalah 1000000 ekor benih per bulan, sedangkan jumlah tenaga kerja yang membantu ada 12 orang dengan upah rata-rata $\operatorname{Rp} 25000$ per hari.

\section{Profil Kelompok Tani Hurip}

Kelompok tani Hurip sudah berdiri sejak tahun 1975 yang didirikan oleh Bapak $H$. Uming yang bertempat di Desa Cikarawang Kecamatan Dramaga Kabupaten Bogor. Kemudian pada tanggal 18 April 2005, membentuk kepengurusan baru dengan ketua kelompok tani yang baru. Latar belakang terbentuknya kelompok tani Hurip adalah disebabkan oleh keinginan petani untuk dapat berdiskusi dan bertukar pengalaman dibidang pertanian. Oleh karena itu, timbulah inisiatif untuk dapat membentuk kelompok tani yang diberi nama kelompok tani Hurip. Melalui kelompok tani ini, para petani dapat menyalurkan aspirasinya dan menjadi wadah pembelajaran bagi para petani desa.

Kelompok tani Hurip memiliki visi dan misi dalam menjalankan kegiatan kelompok taninya. Visi kelompok tani Hurip adalah "Menciptakan kelompok tani mandiri yang dapat meningkatkan pendapatan dan mensejahterakan anggotanya", sedangkan misi kelompok taninya adalah sebagai berikut.

1. Meningkatkan sumber daya anggota kelompok tani

2. Memanfaatkan lahan pertanian semaksimal mungkin

3. Mengakses para anggota kelompok ke lembaga permodalan, pasar, dan informasi teknologi

4. Meningkatkan produktivitas komoditas di wilayah tersebut.

Kelompok tani Hurip memiliki sebanyak 60 anggota dan 11 orang sebagai pengurus inti. Adapun aktivitas kelompok tani hurip adalah sebagai berikut.

1. Pengukuhan tani Hurip

2. SLPHT Padi yang diselenggarakan oleh APP Bogor, atas pertisipasi dan dukungannya dalam kegiatan KKN IPB ke Desa Cikarawang

3. Pemberdayaan petani pelaku agribisnis pedesaan

4. Pelatihan pemanduan di STPP Bogor

5. Penyuluhan dan pelatihan kompos

6. Pengendalian hama Boleng ubi jalar yang ramah lingkungan
7. Mengikuti kursus tani Dinas Pertanian dan Kehutanan

8. Pembuatan tungku sekam dari IPB

9. Seminar dan pelatihan biogas sebagai nara sumber dalam kegiatan seminar dan lokakarya pengabdian masyarakat teknik IPB

10. Pelatihan administrasi dan kelembagaan

11. Pelatihan kompor sekam oleh IPB bekerja sama dengan Himpunan Profesi Agribisnis, IPB

12. Pelatihan koperasi dan kelembagaan agribisnis

13. Kegiatan PKMM, pengembangan usaha tani ubi jalar dan peningkatan nilai tambah

\section{Faktor Personal Anggota Kelompok Tani}

\section{Usia}

Secara umum usia petani tergolong pada kategori usia produktif, yaitu kisaran 15 sampai 64 tahun. Usia produktif petani (kisaran 15-64 tahun) pada kelompok tani Hurip lebih tinggi dibandingkan dengan usia produktif petani pada kelompok tani Bina Sejahtera, tetapi petani yang tergolong usia tua lebih tinggi kelompok tani Bina Sejahtera dibandingkan dengan kelompok tani Hurip. Adapun kategori petani pada usia muda yaitu usia di bawah 15 tahun dinyatakan tidak ada, baik pada kelompok tani Bina Sejahtera maupun kelompok tani Hurip.

\section{Tingkat Pendidikan}

Tingkat pendidikan pada petani di kelompok tani Bina Sejahtera dan kelompok tani Hurip dinyatakan rendah. Pernyataan ini sesuai dengan hasil penelitian yang dilakukan oleh Cepriadi dan Yulida (2012) di Kecamatan Kerinci Kabupaten Pelalawan. Pendidikan petani masih rendah yaitu hanya sampai tamat SD bahkan masih ada petani yang tidak tamat SD. tingkat pendidikan petani pada kelompok tani Bina Sejahtera lebih tinggi dibandingkan dengan kelompok tani Hurip. Tingkat pendidikan petani secara rinci dapat dilihat pada Tabel 2.

Tabel 2 menunjukkan bahwa tingkat pendidikan petani pada kelompok tani Bina Sejahtera lebih tinggi dibandingkan dengan kelompok tani Hurip. Tingkat pendidikan petani pada kategori sedang (tamat SMP/Sederajat dan/ SMA/ sederajat) juga lebih tinggi kelompok tani Bina Sejahtera dibandingkan dengan kelompok tani Hurip. Adapun tingkat pendidikan yang tergolong pada ketegori rendah (tidak tamat SD atau tamat SD/Sederajat) menunjukkan selisih paling besar yang mana pendidikan terendah adalah petani pada kelompok tani Hurip dibandingkan dengan kelompok tani Bina Sejahtera.

Tabel 2. Persentase Tingkat Pendidikan Petani Pada Kelompok Tani Bina Sejahtera dan Kelompok Tani Hurip, Tahun 2014

\begin{tabular}{ccc}
\hline $\begin{array}{c}\text { Tingkat } \\
\text { Pendidikan }\end{array}$ & $\begin{array}{c}\text { Poktan Bina Sejahtera } \\
(\%)\end{array}$ & $\begin{array}{c}\text { Poktan Hurip } \\
(\%)\end{array}$ \\
\hline Rendah & 35.72 & 67.86 \\
Sedang & 57.14 & 32.14 \\
Tinggi & 7.14 & 0.00 \\
Total & 100.00 & 100.00 \\
\hline
\end{tabular}




\section{Luas Lahan}

Luas lahan petani pada kedua kelompok tani tergolong sempit. Luas lahan yang dimiliki petani dibagi menjadi tiga kategori, yaitu kategori sempit (rendah) jika petani memiliki luas lahan kurang dari $9000 \mathrm{~m} 2$, cukup luas (sedang) jika petani memiliki luas lahan kisaran 9000 sampai 16000 $\mathrm{m} 2$, dan sangat luas (tinggi) jika petani memiliki luas lahan lebih dari lebih dari $16000 \mathrm{~m} 2$.

Luas lahan petani sempit tergolong tinggi pada petani di kelompok tani Hurip dari pada kelompok tani Bina Sejahtera. Petani yang mempunyai lahan cukup luas, yaitu lebih tinggi pada kelompok tani Bina Sejahtera dibandingkan dengan kelompok tani Hurip. Kepemilikan lahan sangat luas lebih tinggi kelompok tani Bina Sejahtera dibandingkan dengan kelompok tani Hurip. Hal ini menunjukkan bahwa area luas lahan yang lebih besar terdapat pada kelompok tani Bina Sejahtera.

\section{Status Kepemilikan Lahan}

Secara umum petani mempunyai lahan untuk usaha tani dengan status lahan milik sendiri, namun ada juga petani yang tidak memiliki lahan. Petani yang tidak memiliki lahan bukan berarti tidak mempunyai kesempatan untuk melakukan usahatani. Petani menggunakan beberapa istilah dalam memberikan label terhadap lahan yang status lahannya bukan milik sendiri di antaranya gade, maparo, dan ngepak. Gade merupakan istilah sewa tanah dari orang yang membutuhkan uang dengan memberikan jaminan berupa lahan yang dapat digarap, tetapi sewaktu-waktu lahan tersebut dapat diambil kembali dengan syarat uang yang dipinjami sudah dikembalikan. Maparo merupakan istilah orang sunda yang artinya "separuh-separuh". Petani yang tidak memiliki lahan dapat menggunakan lahan orang lain dengan ketentuan lahan digarap dan diberikan modal oleh petani berupa pupuk, obat-obatan, dan bibit. Hasil atas garapan lahan dibagi menjadi dua antara orang yang memiliki lahan dan petani yang mengelola lahan tersebut. Selanjutnya adalah Ngepak, Ngepak merupakan istilah yang digunakan untuk petani penggarap dengan ketentuan status kepemilikan lahan merupakan milik orang lain dan diberikan modal berupa bibit, obat-obatan dari orang yang memiliki lahan. Hasil dari lahan garapan tersebut kemudian dibagi menjadi $2: 1$ atau $3: 1$ atau $5: 1$ sesuai dengan kesepakatan awal.

Melihat kondisi di lapangan bahwa status lahan milik petani pada kelompok tani Bina Sejahtera lebih tinggi dibandingkan dengan lahan yang berstatus milik petani pada kelompok tani Hurip. Kepemilikan lahan yang bukan milik sendiri lebih tinggi kelompok tani Hurip dibandingkan dengan kelompok tani Bina Sejahtera. Artinya, lahan yang diolah pada kelompok tani Bina Sejahtera kebanyakan merupakan lahan milik sendiri dibandingkan dengan petani yang mengelola lahan pada kelompok tani Hurip.

\section{Pengalaman Usaha Tani}

Hasil penelitin di lapang menunjukkan bahwa pengalaman petani dalam berusaha tani digolongkan rendah dengan pengalaman usaha tani kurang dari 26 tahun. Pengalaman usahatani dibagi ke dalam tiga kategori yaitu tergolong kategori rendah jika pengalaman berusaha tani kurang dari 26 tahun, tergolong kategori sedang jika pengalaman berusaha tani berada pada kisaran 26 sampai 48 tahun dan tergolong tinggi jika pengalaman berusaha tani lebih dari 48 tahun. Secara rinci distribusi petani terhadap pengalaman usaha tani dapat dilihat pada Tabel 3.

\section{Tabel 3. Persentase Pengalaman Usaha Tani Petani Dikelompok Tani Bina Sejahtera dan Kelompok Tani Hurip, Tahun 2014}

\begin{tabular}{ccc}
\hline $\begin{array}{c}\text { Tingkat } \\
\text { Pendidikan }\end{array}$ & $\begin{array}{c}\text { Poktan Bina Sejahtera } \\
(\%)\end{array}$ & $\begin{array}{c}\text { Poktan Hurip } \\
(\%)\end{array}$ \\
\hline Rendah & 53.57 & 35.72 \\
Sedang & 32.14 & 32.14 \\
Tinggi & 14.29 & 32.14 \\
Total & 100.00 & 100.00 \\
\hline
\end{tabular}

Pengalaman petani dalam berusaha tani menunjukkan perbedaan antara petani pada kelompok tani Bina Sejahtera dan petani pada kelompok tani Hurip. Tabel 3 menunjukkan bahwa pengalaman petani pada kelompok tani Hurip dalam berusaha tani tergolong tinggi dibandingkan kelompok tani Bina Sejahtera. Kemudian pengalaman usaha tani yang tergolong rendah (kurang dari 26 tahun) lebih tinggi pada kelompok tani Bina Sejahtera dibandingkan dengan petani pada kelompok tani Hurip. Adapun pengalaman petani pada kategori sedang tidak ada perbedaan, baik kelompok tani Bina Sejahtera maupun kelompok tani Hurip.

\section{Faktor Lingkungan}

\section{Akses Lahan}

Secara umum akses lahan petani pada kelompok tani Bina Sejahtera dan kelompok tani Hurip tergolong tinggi. Akan tetapi, petani yang beranggapan bahwa akses terhadap lahan yang subur kurang memadai dikarenakan kurang maksimalnya air yang mengalir pada kolam-kolam milik petani di kelompok tani Bina Sejahtera dan terjadinya kekurangan air pada pesawahan milik petani di kelompok tani Hurip.

Akses lahan pada kelompok tani Bina Sejahtera dan kelompok tani Hurip mempunyai perbedaan karena wilayahnya berbeda. Kelompok tani Bina Sejahtera yang berada di Desa Situ Udik Kecamatan Cibungbulang Kabupaten Bogor terletak pada daerah dataran tinggi. Aliran sungai yang dijadikan irigasi untuk pesawahan, kolam, dan sayur-sayuran masih tersedia. Sedangkan, lokasi kelompok tani Hurip berada di Desa Cikarawang Kecamatan Dramaga Kabupaten Bogor yang merupakan lokasi daerah dataran rendah. Awalnya pengairan untuk lahan pertanian pada anggota kelompok tani Hurip ini menggunakan sistem irigasi dari Bubulak, namun sistem irigasi tersebut sering tersendat akibat kurangnya kontrol dari petani yang bertugas sebagai ulu-ulu. Oleh karena itu, sistem pengairan pada kelompok tani bukan lagi menggunakan sistem irigasi melainkan menggunakan sistem pengairan tadah hujan. Sistem pengairan tadah hujan ini merupakan aliran air yang memanfaatkan bendungan Situ Gede sebagai sumber air, namun jika tiba musim kemarau aliran air untuk pesawahan tidak akan maksimal.

Akses lahan pada kelompok tani Bina Sejahtera lebih tinggi dibandingkan dengan kelompok tani Hurip. Adapun akses 
lahan yang tergolong sedang lebih tinggi kelompok tani Hurip dibandingkan dengan kelompok tani Bina Sejahtera. Melihat perbedaan ini, petani yang memiliki lahan subur dengan dukungan dari lingkungan sekitar kelompok tani pada petani di kelompok tani Bina Sejahtera.

\section{Ketersediaan Saprodi}

Saprodi atau sarana produksi merupakan sebuah sarana atau alat pendukung yang digunakan petani untuk usaha tani. Saprodi terutama bibit, pupuk, dan obat-obatan merupakan alat yang digunakan dalam menjalankan usahatani. Ketersediaan saprodi tergolong tinggi, baik pada kelompok tani Bina Sejahtera maupun pada kelompok tani Hurip, namun ada juga petani yang beranggapan bahwa ketersediaan saprodi tergolong sedang. Anggapan tersebut diungkapkan karena ketersediaan saprodi belum di pasilitasi secara maksimal.

Sarana produksi pada kelompok tani Bina Sejahtera tergolong tinggi dibandingkan dengan kelompok tani Hurip. Pada kelompok tani Bina Sejahtera, petani yang aktif tergabung dalam kelompok tani mempunyai jatah mendapatkan bibit pertanian dan obat-obatan dari kelompoknya. Biasanya kelompok tani mendapatkan bibit padi dari pemerintah tiga bulan sekali dan petani harus menebusnya sebesar Rp10 000 per kantong, sedangkan pada kelompok tani Hurip sudah tidak ada lagi pasokan dari pemerintah. Sarana produksi yang ada pada kelompok tani Bina Sejahtera juga bukan hanya bibit dan obatobatan padi sawah, melainkan bibit jagung dan benih ikan. Bibit jagung dan ikan merupakan hasil pertanian yang dijadikan produk oleh kelompok tani Bina Sejahtera. Lain halnya dengan kelompok tani Hurip, biasanya membuat bibit sendiri jika panen padinya bagus, namun jika bibit padinya kurang bagus petani biasanya membeli bibit di toko pertanian, sedangkan untuk bibit ubi jalar dan kacang didapatkan dari tengkulak. Akan tetapi, hasil panen ubi jalar tersebut harus di jual kembali kepada tengkulak yang memberikan bibit. Untuk itu, hasil panen pada petani di kelompok tani Bina Sejahtera lebih bebas dibandingkan dengan petani pada kelompok tani Hurip.

\section{Kemudahan Pemasaran Hasil}

Memasarkan hasil usaha tani terbilang mudah, petani tinggal menjual hasil panennya kepada para pengempul atau tengkulak. Pemasaran hasil usaha tani pada kedua kelompok dinilai tinggi. Adapun pemasaran hasil yang terbilang sulit termasuk pada kategori sedang dan rendah. Data distribusi petani terhadap kemudahan pemasaran hasil menunjukkan bahwa lebih mudah pemasaran pada kelompok tani Hurip dibandingkan dengan kelompok tani Bina Sejahtera. Mudahnya pemasaran pada kelompok tani Hurip disebabkan oleh adanya tengkulak yang siap menerima hasil komoditas pertanian yang ditanam dengan cara meminjami modal berupa bibit dan obat-obatan kepada petani. Akan tetapi, ada juga petani yang tidak meminjam bibit ubi jalar kepada tengkulak melainkan membuat bibit sendiri dari hasil panen sebelumnya dan kemudian menjual hasil panen kepada tengkulak lain yang harga belinya lebih tinggi dan ada juga yang menjualnya sendiri langsung kepada konsumen yang terkadang ubi jalar langsung habis terjual. Inilah alasan mengapa dari satu kelompok terdapat perbedaan pandangan. Selain pemasaran kepada tengkulak dan konsumen langsung, kelompok tanipun menyediakan pemasaran ubi dan kacang.
Untuk menjual ubi jalar dan kacang-kacangan, kelompok tani menyediakan pemasaran dengan harga pembelian kisaran Rp1 100 sampai dengan Rp1 500 per kilo tergantung bagus tidaknya produk pertanian yang dihasilkan. Jika mendengar pemaparan salah satu pengurus kelompok, harga beli yang ditetapkan oleh pemerintah adalah Rp2 000 per kilo, tetapi pada kenyataannya harga beli yang diberlakukan maksimal sebesar Rp1 500. Pembelian yang dilakukan oleh kelompok tani tersebut kemudian menjualnya hasil pertanian ke daerah Tanggerang untuk dibuat saos dan sebagian lagi untuk dikelola oleh kelompok tani dibuat terigu ubi jalar.

\section{Potensi Pengembangan Usaha Tani}

Secara umum potensi petani terhadap pengembangan usaha tani tergolong tinggi. Hal ini menunjukkan bahwa petani mempunyai potensi pengembangan usaha dengan inovasi yang tinggi, yaitu dapat menciptakan wirausaha tani dari hasil usaha tani ubi jalar berupa saos dan tepung ubi jalar, serta dapat menjadi wirausaha tani dari produk jagung dan ikan yang berupa kemasan bibit jagung, crispy ikan nila dan dendeng ikan nila. Akan tetapi, potensi pengembangan usahatani pada kelompok tani Bina Sejahtera dan kelompok tani Hurip sedikit ada perbedaan potensi.

Pada kelompok tani Hurip pemasaran hasil usaha tani sudah baik dilakukan dalam hal pengemasan untuk bahan hasil usahatani terutama dari bahan baku ubi jalar. Kelompok tani Hurip membuat inovasi baru dari bahan baku ubi jalar menjadi tepung terigu dan saos. Petani yang tergabung dalam kelompok tani Hurip ikut membantu dalam proses pembuatan saos dan tepung ubi jalar tersebut. Akan tetapi, inovasi tersebut tidak dibuat secara berkelompok. Artinya, tidak semua anggota terlibat dalam aktivitas penggilingan tepung dan pengolahan saos. Pembelian yang dilakukan kelompok tani kepada masing-masing petani hanya bahan baku ubi jalar yang sudah di kupas. Berbeda dengan kelompok tani Bina Sejahtera pengembangan usaha tani sudah mulai dijalankan. Hanya saja inovasi terhadap pengembangan usaha tani dilakukan pada pembudidayaan ikan dan petani jagung saja. Ikan dijadikan bahan baku untuk membuat crispy dan dendeng, sedangkan jagung dikemas menjadi bibit jagung.

\section{Dukungan Kepemimpinan Kelompok}

\section{Peran Pemimpin Kelompok}

Pemimpin kelompok memiliki peranan yang sangat penting dalam mengelola kelompok taninya. Peran pemimpin kelompok meliputi kemampuan pemimpin dalam memberikan arahan dan tuntunan bagi anggota kelompoknya, mampu memfasilitasi agar tercapai tujuan, mampu mendinamiskan para anggota untuk aktif, dan mampu dalam menampung aspirasi anggota kelompoknya. Peran kepemimpinan pada kedua kelompok tergolong tinggi. Akan tetapi pada kedua kelompok juga tergolong sedang karena penilaian anggota kelompok tani terhadap peran kepemimpinan berbeda-beda.

Peran kepemimpinan pada kelompok tani Hurip jauh lebih tinggi dibandingkan dengan peran kepemimpinan pada kelompok tani Bina Sejahtera. Hal ini disebabkan karena kondisi pemimpin pada kedua kelompok tani sangat berbeda. Pemimpin kelompok tani Hurip konsen pada 
pekerjaan dibidang pertanian dan memiliki banyak waktu luang dalam berusaha tani, sedangkan pemimpin pada kelompok tani Bina Sejahtera dinilai kurang konsen tidak konsen terhadap pekerjaan dibidang pertanian, karena pemimpin kelompok tani Bina Sejahtera mempunyai fokus pada pekerjaan dibidang lain.

\section{Perilaku Kepemimpinan}

Perilaku kepemimpinan merupakan kemampuan pemimpin dalam memperlihatkan tingkah laku layaknya sebagai seorang pemimpin. Perilaku kepemimpinan pada kedua kelompok dinilai tinggi, Artinya perilaku kepemimpinan ini telah diterapkan oleh pemimpin, baik pemimpin kelompok tani Bina Sejahtera maupun pemimpin kelompok tani Hurip. Persepsi petnai terhadap perilaku kepemimpinan kelompok tani Bina Sejahtera lebih tinggi dari kelompok tani Hurip. Pemimpin pada kelompok tani Bina Sejahtera selalu membuat suasana menyenangkan dan selalu menjaga keharmonisan kelompok tani meskipun pada kenyataannya pemimpin disibukkan dengan pekerjaan lain.

\section{Gaya Kepemimpinan}

Pemimpin pada kelompok tani Bina Sejahtera dan kelompok tani Hurip sudah menunjukkan gaya kepemimpinan dengan baik dan gaya kepemimpinan pada kedua kelompok tani juga tergolong tinggi. Gaya kepemimpinan diukur dengan beberapa kemampuan pemimpin di antaranya kemampuan pemimpin dalam menampung aspirasi dan membina hubungan dengan anggota, kemampuan dalam membuat keputusan, kemampuan dalam membagi tugas dan pekerjaan, serta kemampuan mengatur dan mendisiplinkan anggota.

Persepsi petani terhadap gaya kepemimpinan kelompok tani Hurip lebih tinggi dibandingkan dengan kelompok tani Bina Sejahtera. Hal ini disebabkan karena pemimpin kelompok tani Hurip memiliki waktu luang yang banyak dalam mengelola kelompoknya. Pemimpin mampu memberikan arahan sesuai dengan situasi dan kebutuhan anggotanya. Namun, dalam pengambilan keputusan pemimpin jarang mendiskusikannya dengan anggota. Terkadang pemimpin masih belum tegas dalam menerapkan aturan-aturan yang ada di dalam kelompok. Aturan yang berlaku adalah anggota harus menjual hasil tanam kepada kelompok, tetapi pada kenyataannya terdapat beberapa anggota yang masih menjual hasil tani kepada tengkulak di luar kelompok. Adapun setiap keputusan pada kelompok tani Bina Sejahtera ditentukan oleh pemimpin dengan asumsi bahwa petani sudah mendiskusikannya dan sudah dimusyawarahkan bersama. Misalnya keputusan tentang permasalahan hama yang tidak dapat diatasi kelompok sehingga meminta pemimpin untuk mendatangkan penyuluh.

\section{Proses Pemberdayaan Anggota Kelompok Tani}

\section{Pendampingan}

Pendampingan merupakan upaya pembinaan yang dilakukan agar kelompok tetap aktif dan berkembang. Teknik pendampingan dilakukan oleh penyuluh pertanian. Pada kelompok tani Bina Sejahtera, tingkat intensitas atau frekuensi pendampingannya sangat tinggi. Hal ini dikarenakan fokus dari kelompok tani Bina Sejahtera adalah pembudidayaan ikan dan pembibitan jagung yang mana petani masih membutuhkan pembinaan mengenai budi daya ikan. Selain itu, pendampingan dilakukan lebih intensif karena pembudidayaan ikan akan diikutsertakan dalam lomba se-Jawa Barat. Meskipun demikian, penyuluh juga tetap memperhatikan anggota yang fokus terhadap palawija, padi, dan jagung. Lain halnya dengan kelompok tani Hurip, penyuluh pertanian terfokus pada ubi jalar, kacang-kacangan, dan padi.

Intensitas pendampingan dilakukan sangat sering yaitu sebanyak satu bulan dua kali penyuluh datang kepada kelompok Hurip. Akan tetapi penyuluh sudah tidak lagi mendampingi dikarenakan penyuluh yang biasa mendampingi sudah wafat. Sebenarnya, pendampingan yang dilakukan terhadap kelompok tani Hurip sampai saat ini masih berjalan dengan penyuluh baru, tetapi tidak sesering yang dilakukan oleh pendamping yang lama. Namun, hal ini tidak membuat kelompok tani Hurip redup karena selain pertanian merupakan tumpuan petani untuk dapat memenuhi kebutuhannya juga selalu ada pendampingan yang dilakukan oleh mahasiswa IPB.

Pendampingan dilakukan oleh penyuluh dengan cara melakkukan penyuluhan kepada para petani yang tergolong pada kelompok tani. Teknik pendampingan tersebut dilakukan dengan dua cara, yaitu penyuluhan dengan cara ceramah yaitu pemberian materi dan praktek langsung di lapang. Cara seperti ini dilakukan oleh pendamping baik pada kelompok tani Bina Sejahtera maupun pada kelompok tani Hurip.

\section{Tingkat Partisipasi}

Partisipasi merupakan keterlibatan anggota kelompok tani secara aktif dalam mengikuti kegiatan pemberdayaan. Bentuk partisipasi petani di kedua kelompok tergolong tinggi. Akan tetapi tingkat partisipasi anggota kelompok tani Bina Sejahtera dengan tingkat partisipasi anggota kelompok tani Hurip berbeda, dapat dilihat pada Tabel 4.

Tabel 4. Persentase Tingkat Partisipasi Petani Tahun 2014

\begin{tabular}{lcc}
\hline $\begin{array}{l}\text { Tingkat } \\
\text { partisipasi }\end{array}$ & $\begin{array}{c}\text { Poktan Bina Sejahtera } \\
(\%)\end{array}$ & $\begin{array}{c}\text { Poktan Hurip } \\
(\%)\end{array}$ \\
\hline Rendah & 3.57 & 14.29 \\
Sedang & 35.71 & 39.28 \\
Tinggi & 60.72 & 46.43 \\
Total & 100.00 & 100.00 \\
\hline
\end{tabular}

Partisipasi pada kelompok tani Bina Sejahtera lebih tinggi dibandingkan dengan anggota kelompok tani Hurip. Hal ini disebabkan oleh kondisi sosial pada lingkungan kedua kelompok berbeda. Pada kelompok tani Bina Sejahtera, masyarakatnya lebih mengutamakan rasa kebersamaan dan mengedepankan ikatan silaturahmi yang kuat diantara satu orang dengan orang lain. Sedangkan pada kelompok tani Hurip, kebanyakan yang menjadi anggota kelompok tani masih memiliki ikatan kerabat yang kuat. Ikatan persaudaraan pada kelompok tani Hurip lebih diutamakan sehingga anggota yang bukan kelompok tani terkadang tersisihkan dari perkumpulan dan pada akhirnya jarang mengikuti perkumpulan. 


\section{Keberdayaan Anggota Kelompok Tani}

Tingkat keberdayaan anggota kelompok tani diukur dari kemampuan petani berwirausaha dan kemandirian dalam berwirausaha. Kedua aspek ini diukur melalui tiga aspek perilaku, yaitu tingkat pengetahuan, kecenderungan sikap, dan tingkat keterampilan. Secara umum, petani yang diberdayakan melalui kelompok tani cenderung memiliki tingkat keberdayaan yang tinggi. Hal ini dibuktikan dengan tingkat pengetahuan petani tentang pengelolaan resiko, permodalan, dan pemasaran yang tinggi, kemudian sikap yang positif terhadap inovasi dan keberlanjutan usaha tani yang dijalankan, juga tingkat keterampilan yang baik dalam berusaha tani.

Berdasarkan hasil penelitian di lapang bahwa tingkat keberdayaan petani pada kelompok tani Bina Sejahtera lebih tinggi dibandingkan kelompok tani Hurip. Hal ini dipengaruhi oleh tingkat pendidikan yang tinggi yang memungkinkan petani lebih mampu menyerap informasi dan pembelajaran lebih cepat baik pembelajaran dari pendampingan maupun dari lingkungannya. Tingkat pengetahuan dalam mengelola resiko usaha tani, permodalan, dan pemasaran dinilai tinggi, karena masyarakat yang memang mengerti akan resiko usaha tani dan kaitannya terhadap modal dan pemasaran. Ada sebagian petani yang meminjam modal kepada lembaga keuangan seperti Bank, koperasi, dan Lembaga Keuangan Mikro yang ada di wilayahnya. Peminjaman modal tersebut dilakukan ketika tidak ada cara lain untuk dapat menutupi kekurangan modal untuk usaha. Akan tetapi, peminjaman modal tersebut tidak hanya digunakan untuk pertanian saja melainkan sebagian modal digunakan untuk usaha lain seperti menambah modal warung, penggilingan, dan toko. Penggunaan modal dilakukan tidak hanya untuk pertanian karena mereka sadar bahwa tidak selamanya usaha tani menguntungkan. Pemasaran yang dilakukan petani di kelompok tani Bina Sejahtera juga lebih menguntungkan masyarakat. Pemasaran untuk padi, petani langsung menjual kepada tetangganya yang memiliki toko padi di pasar, pembibitan jagung juga dijual langsung kepada kelompok tani lain atau petani lain yang membutuhkan, serta pembibitan nila juga langsung di jual kepada pembudidaya pembesaran ikan sehingga hasil dari penjualan tidak merugikan petani.

Tingkat keberdayaan petani pada kelompok tani Hurip lebih banyak pada tingkat keberdayaan yang tergolong sedang. Hal ini dikarenakan oleh tingkat pengetahuan tentang resiko usaha tani tinggi tetapi masih belum mampu mengatasi masalah jika ada kesulitan dalam mencari modal untuk usaha tani. Petani kerap meminjam uang atau modal kepada tengkulak yang hasilnya nanti harus dijual kembali kepada tengkulak tersebut dengan harga di bawah harga jual yang telah ditetapkan oleh pemerintah. Selain itu, petani juga belum mampu membuat inovasi terhadap komoditas yang ditanamnya untuk mendapatkan hasil usaha tani yang lebih menguntungkan. Pemasaran yang dilakukan hanya sebatas kepada tengkulak dan kelompok tani yang juga dianggap tengkulak oleh petani.

\section{Hubungan Kepemimpinan dengan Proses Pemberdayaan Anggota Kelompok Tani}

Dukungan kepemimpinan menunjukkan hubungan nyata positif dengan proses pemberdayaan. Semakin tinggi dukungan kepemimpinan maka semakin tinggi pula proses pemberdayaan terhadap petani. Maknanya bahwa hipotesis yang menyatakan bahwa "Terdapat hubungan nyata antara kepemimpinan (peran kepemimpinan, perilaku kepemimpinan, gaya kepemimpinan) dengan proses pemberdayaan (pendampingan, tingkat partisipasi)" terbukti.

Semua variabel pada dukungan kepemimpinan menunjukkan hubungan nyata positif dengan variabel proses pemberdayaan yang meliputi pendampingan dan tingkat partisipasi. Semakin tinggi peran kepemimpinan, perilaku kepemimpinan, dan gaya kepemimpinan maka semakin tinggi pula pendampingan dan tingkat partisipasi. Pendampingan dan tingkat partisipasi pada masing-masing kelompok tani berbeda.

Pada kelompok tani Bina Sejahtera menunjukkan hubungan nyata positif antara variabel peran kepemimpinan dan gaya kepemimpinan dengan pendampingan, dan menunjukkan hubungan yang sangat nyata positif pada variabel perilaku kepemimpinan dengan pendampingan. Akan tetapi, pada kelompok tani Hurip menunjukkan hubungan yang sangat nyata positifantara semua variabel dukungan kepemimpinan dengan pendampingan. Pada kedua kelompok tani ini, peran kepemimpinan, perilaku kepemimpinan, dan gaya kepemimpinan dianggap penting. Pemimpin dianggap sebagai kunci utama masuknya kegiatan pemberdayaan dari pihak penyuluh, akademisi, atau pihak lain yang ingin melakukan kegiatan pemberdayaan bagi petani pada daerah tersebut.

Kegiatan kepemimpinan pada kelompok tani Bina Sejahtera sering kali memberikan tanggung jawab kepada istrinya dalam mengelola kelompok tani. Hal ini dikarenakan ketua kelompok memiliki pekerjaan lain di luar kegiatan pertanian. Pada kelompok tani Hurip, pemimpin memiliki kewajiban utama mengurusi perkembangan kelompoknya karena kelompok tani tersebut merupakan salah satu sumber penghasilan bagi ketua. Istri dari ketua kelompok tani Hurip memiliki jabatan sebagai bendahara kelompok, sehingga tidak heran jika istri pemimpin ikut berperan dalam kegiatan kelompok tani. Disamping itu, pemimpin kelompok tani Hurip menjadikan pertanian sebagai penghasilan utama. Oleh karena itu, kelompok memiliki alat untuk membuat tepung terigu dan petani sebagai pemasok bahan baku dari tepung ubi jalar tersebut.

Hubungan antara kepemimpinan dengan tingkat partisipasi menunjukkan bahwa terdapat hubungan sangat nyata positif antara variabel peran kepemimpinan dan perilaku kepemimpinan dengan tingkat partisipasi, namun tidak menunjukkan hubungan nyata antara gaya kepemimpinan dengan tingkat partisipasi anggota kelompok tani. Hal ini disebabkan karena pemimpin kurang mampu mendisiplinkan anggota untuk mau dan ikut terlibat dalam kegiatan penyuluhan. Sebelum pertemuan dimulai pemimpin memberikan surat undangan kepada setiap anggota agar ikut berpartisipasi dalam kegiatan penyuluhan, namun terkadang anggota tidak dapat mengikuti kegiatan penyuluhan karena jadwal pertemuan bentrok dengan jadwal pekerjaan utama di bidang non-pertanian. Pemimpin juga dianggap kurang mampu dalam membagi tugas-tugas kelompok dengan baik.

Hubungan nyata positifantara peran kepemimpinan, perilaku kepemimpinan, dan gaya kepemimpinan dengan tingkat partisipasi petani. Semakin tinggi peran kepemimpinan, perilaku kepemimpinan, gaya kepemimpinan maka semakin tinggi tingkat partisipasi petani dalam mengikuti kegiatan 
kelompok tani. Persepsi petani terhadap kepemimpinan ketua kelompok tani dinilai positif, karena anggota merasa pemimpin telah menjalankan tugas-tugasnya dengan baik. Pemimpin kelompok tani Hurip mampu memberikan tugas dengan baik kepada anggota, mengatur dan mampu mendisiplinkan kegiatan yang ada di dalam kelompok tani, mampu mengenal semua anggota kelompoknya, dan dianggap mampu menampung aspirasi anggota serta mampu membangun struktur kepengurusan berdasarkan musyawarah. Akan tetapi, ada sebagian petani yang juga memiliki persepsi negatif terhadap pemimpin terutama pada kelompok tani Hurip. Hal ini disebabkan pemimpin kurang transparan dalam menyampaikan bantuan-bantuan yang diterima dari pihak luar seperti: pemerintah, akademisi, atau organisasi lainnya.

\section{Hubungan Antara Proses Pemberdayaan Petani dengan Tingkat Keberdayaan Petani}

Proses pemberdayaan tidak menunjukkan hubungan nyata dengan tingkat keberdayaan. Proses pemberdayaan yang meliputi pendampingan dan tingkat partisipasi juga tidak menunjukkan hubungan nyata dengan tingkat keberdayaan. Maknanya bahwa, hipotesis yang menyatakan "Terdapat hubungan nyata antara proses pemberdayaan (pendampingan, tingkat partisipasi) dengan tingkat keberdayaan" tidak terbukti.

Pendampingan yang dilakukan penyuluh secara umum tidak dilakukan kepada tiap-tiap petani melainkan dilakukan secara berkelompok, menyebabkan pendapingan dilakukan secara berkelompok sehingga terkadang pendamping tidak mengetahui potensi masing-masing individu khususnya potensi dalam berusaha tani. Tingkat partisipasi petani dalam mengikuti kegiatan penyuluhan hanya sebatas penyuluhan tentang tata cara bertani dan sebagai jembatan antara petani dengan pemerintah dalam akses bantuan berupa bibit dan alat-alat produksi pertanian, sehingga tingkat keberdayaan yang meliputi pengetahuan, sikap, dan keterampilan dalam kemandirian petani mendapatkan modal dan pengelolaan berusaha tani tidak tersentuh.

Secara rinci menunjukkan bahwa pada kelompok tani Bina Sejahtera tidak menunjukkan hubungan nyata antara pendampingan dengan tingkat keberdayaan, sedangkan tingkat partisipasi menunjukkan hubungan nyata positif dengan tingkat keberdayaan. Semakin tinggi tingkat partisipasi petani dalam mengikuti kegiatan penyuluhan maka semakin tinggi tingkat keberdayaan petani. Pendampingan yang dilakukan penyuluh memberikan manfaat kepada petani sendiri dalam hal mendapatkan bibit, alat-alat produksi ikan, membantu meningkatkan pemasaran produksi kelompok tani Bina Sejahtera berupa ikan crispy, bibit jagung, bibit ikan untuk pembesaran, dan dendeng ikan. Selain itu, tingkat keberdayaan petani yang dilihat dari tingkat pengetahuan, sikap, dan keterampilan juga disebabkan karena anggota kelompok tani Bina Sejahtera sudah memiliki perhitungan sendiri dalam menggunakan modal untuk usaha tani dan dalam memprediksi resiko. Petani pada kelompok tani Bina Sejahtera umumnya memiliki usaha lain dibidang nonpertanian sehingga dinilai mampu mengurangi resiko dibidang pertanian.

Hubungan pendampingan dan tingkat partisipasi dengan tingkat keberdayaan tidak menunjukkan hubungan nyata pada kelompok tani Hurip. Artinya, setinggi apapun tingkat partisipasi yang diikuti oleh anggota terhadap kegiatan pemberdayaan tidak memberikan dampak yang nyata terhadap kehidupan petani itu sendiri. Petani pada kelompok tani Hurip sudah terbiasa bekerja sama dengan tengkulak sistem pembayaran yang lebih ringan dibandingkan dengan pinjam kepada dana PUAP.

\section{Hubungan antara Faktor Personal dan Faktor Lingkungan dengan Proses Pemberdayaan Anggota Kelompok Tani}

\section{Hubungan Faktor Personal dengan Proses Pemberdayaan Anggota Kelompok Tani}

Faktor personal yang meliputi usia dan tingkat pendidikan menunjukkan hubungan nyata positif dengan proses pemberdayaan, sedangkan pengalaman bertani menunjukkan hubungan nyata negatif dengan proses pemberdayaan. Semakin tinggi usia dan tingkat pendidikan petani maka semakin tinggi proses pemberdayaan yang dilakukan. Akan tetapi, semakin tinggi tinggi pengalaman petani dalam berusaha tani maka semakin rendah pendampingan yang dilakukan penyuluh. Hal ini tidak sepenuhnya sejalan dengan hipotesis yang mengungkapkan bahwa "Terdapat hubungan nyata antara faktor personal (usia, tingkat pendidikan, status kepemilikan lahan, luas lahan, pengalaman berusaha tani) dengan proses pemberdayaan (pendampingan, tingkat partisipasi). Hanya sebagian variabel yang hipotesisnya terbukti yaitu: usia, tingkat pendidikan, dan pegalaman bertani.

Dinyatakan bahwa status kepemilikan lahan tidak menunjukkan hubungan nyata dengan proses pemberdayaan. Hasil penelitian mengungkapkan bahwa pendampingan yang tergolong sedang ditunjukkan kepada tiga orang petani yang tidak memiliki lahan dan tujuh orang petani yang memiliki lahan, sedangkan pendampingan yang tergolong tinggi dilakukan terhadap enam orang petani yang tidak memiliki lahan dan 40 orang petani yang memiliki lahan. Hasil ini membuktikan bahwa tingkat pendampingan yang dilakukan penyuluh tergantung kepada hubungan personal antara orang yang memberdayakan dan orang yang diberdayakan.

Hubungan status kepemilikan lahan tidak menunjukkan hubungan nyata. Akan tetapi, hasil penelitian menunjukkan bahwa terdapat dua orang petani yang tidak memiliki lahan dan tiga orang petani yang memiliki lahan tergolong pada tingkat partisipasi rendah. Sebanyak dua orang petani yang tidak memiliki lahan dan 19 orang petani yang memiliki lahan menunjukkan tingkat partisipasi yang tergolong sedang. Kemudian, sebanyak lima orang petani yang tidak memiliki lahan dan 25 orang petani memiliki lahan menunjukkan tingkat partisipasi yang tergolong tinggi. Jumlah petani yang beragam tiga tingkatan partisipasi tersebut merupakan keinginan pada masingmasing individu untuk ikut atau tidaknya dalam kegiatan pemberdayaan.

Faktor personal yang dihubungkan dengan proses pemberdayaan yang dilihat pada masing-masing kelompok tani sangat berbeda. Perbedaan tersebut hanya pada variabel usia dan tingkat pendidikan saja yang memiliki hubungan nyata positif dengan tingkat partisipasi petani di kelompok tani Bina Sejahtera, sedangkan luas lahan dan pengalaman usahatani tidak menunjukkan hubungan nyata baik terhadap pendampingan maupun dengan tingkat partisipasi. Semakin produktif usia anggota dan semakin 
tinggi tingkat pendidikan anggota kelompok tani maka semakin tinggi pula tingkat partisipasi anggota kelompok tani dalam mengikuti kegiatan pemberdayaan. Luas lahan dan pengalaman bertani tidak menunjukkan hubungan yang nyata, artinya luas lahan dan pengalaman bertani tidak menjadi suatu indikator keikutsertaan anggota dalam mengikuti kegiatan penyuluhan.

Selanjutnya, pada kelompok tani Hurip, semua variabel tidak menunjukkan hubungan nyata terhadap pendampingan dan tingkat partisipasi. Hal ini berarti pendampingan yang dilakukan oleh penyuluh tidak ada kaitannya dengan faktor personal. Maknanya bahwa faktor personal tidak dijadikan sebagai indikator untuk penyuluh melakukan pendampingan terhadap anggota kelompok tani. Selain itu, pada petani di kelompok tani Hurip wajib mengikuti kegiatan pemberdayaan tanpa terkecuali dan wajib mematuhi apa yang menjadi aturan yang telah disepakati, sehingga usia petani yang beragam (terdiri dari usia produktif dan usia tua) tetap harus mengikuti kegiatan pemberdayaan baik kegiatan pemberdayaan dari penyuluh, pemerintahan, maupun dari akademisi. Tingkat pendidikan pada petani di kelompok tani Hurip sebagian besar hanya sampai pada lulusan SD dan sebagian kecil adalah lulusan SMP dan SMA. Petani pada kedua tingkatan pendidikan ini tetap mengikuti kegiatan pemberdayaan, sehingga tidak menjamin adanya perbedaan partisipasi petani dalam mengikuti kegiatan pemberdayaan.

Sebanyak 82.14 persen petani memiliki lahan dan sebanyak 17.82 persen petani tidak memiliki lahan untuk digarap. Petani yang memiliki lahan dengan yang tidak memiliki lahan selalu mengikuti apa yang menjadi kehendak kelompok tani berdasarkan musyawarah mufakat, sehingga status kepemilikan lahan ini tidak berhubungan dengan tingkat partisipasi petani dalam mengikuti kegiatan pemberdayaan kelompok tani. Luas lahan yang dimiliki petani terbilang cukup sempit, yaitu kisaran $9000 \mathrm{~m} 2$ hingga $16000 \mathrm{~m} 2$. Luas lahan yang digarap petani juga bukan penentu tinggi rendahnya tingkat partisipasi. Petani senantiasa mengikuti kegiatan jika memang mereka diundang oleh kelompok tani untuk mengikuti kegiatan kelompok tani. Petani lebih menghargai orang luar yang datang memberikan penyuluhan dibandingkan dengan sibuk mengurusi lahan garapan dan ini berlaku baik untuk petani yang sudah berpengalaman lama maupun petani yang pengalamannya baru sedikit. Selain itu, petani di kelompok tani Hurip pada umumnya selalu mendapatkan reward dari pihak luar jika mereka mengikuti kegiatan kelompok tani.

\section{Hubungan Faktor Lingkungan dengan Proses Pemberdayaan Kelompok Tani}

Faktor lingkungan tidak menunjukkan hubungan nyata dengan proses pemberdayaan. Akan tetapi, hasil uji hubungan antar variabel pada faktor lingkungan dengan intensitas pemberdayaan menunjukkan hasil yang berbeda. Hanya kemudahan pemasaran hasil yang menunjukkan hubungan nyata positif dengan intesitas pemberdayaan. Oleh karena itu, hipotesis yang menyatakan bahwa "Terdapat hubungan nyata antara faktor lingkungan (akses lahan, ketersediaan saprodi, kemudahan pemasaran hasil, potensi pengembangan usaha) dengan proses pemberdayaan (pendampingan, tingkat partisipasi)" tidak terbukti sepenuhnya.
Faktor lingkungan meliputi akses lahan, ketersediaan saprodi, kemudahan pemasaran hasil, dan potensi pengembangan usaha dihubungkan dengan proses pemberdayaan yang meliputi pendampingan dan tingkat partisipasi. Faktor personal yang meliputi hubungan nyata positif dengan pendampingan dan tingkat partisipasi adalah variabel kemudahan pemasaran hasil, sedangkan akses lahan, ketersediaan saprodi, dan potensi pengembangan usaha tidak menunjukkan hubungan nyata baik pada pendampingan maupun pada tingkat partisipasi.

Melihat pada masing-masing kelompok tani, maka variabel ketersediaan saprodi dan kemudahan pemasaran hasil menunjukkan hubungan nyata yang positif terhadap pendampingan pada kelompok tani Bina Sejahtera. Artinya, semakin tinggi pendampingan dilakukan maka semakin tinggi ketersediaan saprodi dan kemudahan pemasaran hasil terhadap usaha lain. Pendampingan mempunyai nilai tersendiri di mata petani. Melalui kegiatan pendampingan petani bisa mendapatkan jatah bibit pertanian berupa bibit ikan, bibit jagung, dan bibit padi secara gratis. Melalui pendampingan juga kelompok tani, lebih mudah memasarkan hasil produk pertanian berupa bibit jagung dan ikan kepada kelompok tani lain yang berfokus pada usaha tani jagung dan pembesaran ikan. Sedangkan akses lahan dan potensi pengembangan usaha tidak menunjukkan hubungan yang nyata. Hal ini disebabkan penyuluh menjalankan tugasnya kepada siapa saja yang mau belajar tentang pertanian, baik kepada mereka yang memang memiliki akses terhadap lahan maupun kepada yang tidak memiliki akses terhadap lahan dan potensi pengembangan usaha lebih ditekankan kepada kemampuan masing-masing individu, itu sebabnya variabel akses lahan dan potensi pengembangan usaha tidak berhubungan dengan proses pemberdayaan.

Dukungan lingkungan yang meliputi variabel akses lahan, ketersediaan saprodi, kemudahan pemasaran hasil, dan potensi pengembangan usaha tidak menunjukkan hubungan nyata terhadap intensitas pendampingan pada kelompok tani Hurip. Hal ini disebabkan karena pada akses lahan, ketersediaan saprodi, kemudahan pemasaran hasil, dan potensi pengambangan usaha pada anggota kelompok tani memiliki ciri khas pada individu masing-masing untuk dapat mengembangkan dirinya sendiri dengan cara tersendiri, sehingga pendampingan yang dilakukan hanya berupa pengarahan dan hanya membantu dalam memberikan pengetahuan saja.

Faktor lingkungan dengan tingkat partisipasi anggota kelompok tani Bina Sejahtera tidak menunjukkan hubungan nyata. Akses lahan, ketersediaan saprodi, kemudahan pemasaran hasil, dan potesi pengembangan usaha tidak ditentukan oleh tinggi rendahnya partisipasi petani. Akan tetapi, kesuburan tanah tergantung kepada alam dan usaha dari petani itu sendiri dalam memberikan pupuk atau obat-obatan untuk membuat tanah menjadi tetap subur. Kelancaran irigasi juga ditentukan oleh faktor alam yang mampu menentukan surut tidaknya air irigasi dari aliran sungai dan juga usaha petani dalam merawat kelancaran air irigasi.

Ketersediaan saprodi di kelompok tani Bina Sejahtera terdapat bibit padi, bibit ikan, bibit jagung, dan alat-alat perikanan. Sarana produksi ini dapat di akses dan boleh digunakan oleh petani yang menjadi anggota kelompok tani Bina Sejahtera, namun secara khusus untuk bibit 
jagung hanya boleh di akses oleh petani yang konsen terhadap usaha tani jagung, bibit ikan, dan alat-alat pertanian juga hanya boleh di akses oleh petani yang konsen terhadap budi daya ikan. Kemudian, tinggi atau rendahnya partisipasi tidak menjadi ukuran petani dalam mendapatkan pemasaran hasil usaha tani. Kemudahan pemasaran hasil ditentukan oleh usaha petani itu sendiri, namun bukan berarti petani yang tidak bertisipasi secara nyata pada kegiatan penyuluhan tidak dapat memasarkan hasil usaha taninya. Selain itu, potensi pengembangan usaha dikhususkan pada kemampuan masing-masing individu yang mau atau tidaknya dalam mengembangkan usaha yang dimiliki.

Faktor lingkungan pada kelompok tani Hurip tidak menunjukkan hubungan nyata dengan tingkat partisipasi. Seperti halnya dengan kelompok tani Bina Sejahtera akses lahan pada kelompok tani Hurip juga melihat seberapa besar persepsi petani terhadap kesuburan lahan yang digarapnya. Subur atau tidaknya lahan tergantung dari usaha masing-masing individu dalam memberikan pupuk dan memantau kelancaran irigasi di samping faktor cuaca. Ketersediaan saprodi yang dimiliki oleh kelompok tani Hurip secara nyata hanya dapat di akses oleh keluarga pemimpin kelompok taninya saja. Bibit yang dipergunakan dalam usaha tani merupakan bibit yang dibuat sendiri dan hasil panen ketika kualitas padinya bagus namun untuk bibit ubi jalar dan kacang dapat diperoleh dari tengkulak. Pemasaran hasil usaha tani tergantung dari petani tersebut mendapatkan bibit dan pengembangan usaha yang dimiliki tergantung pada kemampuan masing-masing petani dalam mengembangkan usaha tani yang dijalaninya. Oleh karena itu, dukungan lingkungan yang meliputi akses lahan, ketersediaan saprodi, kemudahan pemasaran hasil, dan potensi pengembangan usaha tidak ditentukan oleh tinggi rendahnya partisipasi petani.

\section{KESIMPULAN DAN SARAN}

\section{Kesimpulan}

1. Semakin tinggi dukungan kepemimpinan terhadap kelompok maka semakin tinggi pendampingan dan tingkat partisipasi petani dalam mengikuti proses pemberdayaan. Pemimpin dapat dikatakan sebagai pintu masuk program pemberdayaan, sebagai penghubung antara kelompok dengan orang luar, dan sebagai jembatan masuknya informasi-informasi penting. Pemimpin juga mempunyai peranan penting untuk dapat mengembangkan kelompok taninya dan mempengaruhi anggotanya untuk mau ikut terlibat dalam kegiatan pemberdayaan. Akan tetapi tidak semua anggota mempunyai keinginan dan tujuan yang sama dengan pemimpin. Beberapa anggota kelompok tani merasa mempunyai hak untuk ikut terlibat dalam mendapatkan informasi yang datang dari pihak luar secara transparan, sehingga persepsi negatif dari anggota kelompok dapat diatasi.

2. Tingkat keberdayaan petani dalam penelitian ini diukur dengan melihat kemampuan petani dalam mendapatkan modal dan kemampuan mengelola usaha tani dengan baik dengan meliputi pengetahuan, sikap, dan keterampilan. Akan tetapi, proses pemberdayaan yang dilakukan penyuluh baru sebatas memberikan penyuluhan tentang tata cara bertani dan pemberian bantuan berupa bibit serta alat-alat produksi pertanian. Penyuluhan mengenai pengelolaan resiko usaha tani dan permodalan belum diberikan sehingga tingkat keberdayaan dalam aspek pengetahuan, sikap, dan keterampilan dlam hal tersebut masih kurang.

3. Faktor personal meliputi usia, tingkat pendidikan, dan pengalaman usaha tani ternyata dapat memberikan dampak terhadap tingginya tingkat partisipasi petani dalam proses pemberdayaan petani. Tingginya petani pada usia produktif dan tingginya tingkat pendidikan petani menjadikan petani sadar akan pentingnya ikut serta daam kegiatan penyuluhan yang diberikan. Sebaliknya, semakin tinggi pengalaman usaha tani petani ternyata meniurunkan tingkat partisipasinya dalam mengikuti proses pemberdayaan.

4. Faktor lingkungan pada kedua kelompok ternyata tidak mempengaruhi jalannya proses pemberdayaan yang dilakukan terhadap petani. Faktor lingkungan yang meliputi akses lahan, ketersediaan saprodi, kemudahan pemasaran hasil, dan potensi pengembangan usaha tani bukan merupakan patokan yang harus dimiliki petani dalam mengikuti kegiatan pemberdayaan. Artinya bahwa kegiatan pemberdayaan bagi petani tetap dilaksanakan baik yang lingkungannya mendukung maupun yang lingkungannya tidak mendukung terhadap kegiatan pertanian karena faktor lingkungan lebih menekankan kepada kemampuan masingmasing petani dalam mengakses lahan, menyediakan sarana produksi, memasarkan hasil, dan mengembangan potensi yang dimiliki. Namun, melihat secara nyata bahwa kemampuan petani dalam memasarkan hasil produksi pertaniannya masih tergantung kepada tengkulak.

\section{Saran}

1. Sebaiknya pendampingan yang dilakukan penyuluh bukan hanya dilakukan untuk kelompok, tetapi untuk petani secara individu agar terlihat secara nyata kebutuhan yang diperlukan.

2. Pendampingan harus dilakukan lebih intensif selama satu bulan sekali atau sesuai waktu yang telah disepakati bersama dan sesuai dengan kebutuhan petani sehingga partisipasi dalam mengikuti penyuluhan bukan berdasarkan reward yang diberikan dari pemerintahan atau pihak pemberdaya.

3. Pemimpin harus lebih transparan dengan anggota terkait dengan bantuan yang diterima untuk mencegah persepsi negatif anggota kelompok tani.

4. Tingginya ketergantungan petani terhadap tengkulak membuat kondisi petani tidak banyak berubah sebelum dan sesudah tergabung dalam kelompok, apalagi bagi petani miskin yang bertumpu hanya pada lahan pertaniannya.

\section{DAFTAR PUSTAKA}

Agus NF. 2009. Keberdayaan dan Strategi Pelaksanaan Penyuluhan Masyarakat Nelayan Kota Bengkulu [disertasi]. [Internet]. [Diunduh2013 Des3]:Fakultas Ekologi Manusia, Institut Pertanian Bogor(ID). Tersedia pada: http://skpm.fema.ipb.ac.id/ppn/ wpcontent/uploads/2012/08/KEBERDAYAANDAN-STRATEGI-PELAKSANAAN.pdf

Andrew J, Dubrin. 2006. The Complete Idiot's Guides to 
Leadership 2nd Edition. Jakarta(ID): Prenanda.

Ellis, F., 2000. Rural livehoods and diversity in developing countries. New York: Oxford University press

Arisudana I, Helmi AF. 2009. Kepemimpinan Transformasional Kepercayaan dan Berbagai Pengetahuan dalam Organisasi. Jurnal Psikologi. [Internet]. [Diunduh 2013 Okt 14]; Vol 36(02): Fakultas Psikologi Universitas Gajah Mada (ID). Tersedia pada: http://jurnal.psikologi.ugm.ac.id/ index.php/fpsi/article/view/44.

[BKKBN] Kantor Menteri Negara Kependudukan. 1995. Transisi Demografi, Transisi Pendidikan, dan Transisi Kesehatan di Indonesia. Jakarta (ID).

[BP4K] Badan Pusat Pertanian Perikanan Peternakan dan Kehutanan Kabupaten Bogor. Data Kelompok Tani Tahun 2013

[BPS] Badan Pusat Statistik. 2014. Profil Kemiskinan di Indonesia Maret 2013.

Cepriadi, Yulida R. 2012. Persepsi Petani Terhadap Usahatani Lahan Pekarangan (Studi Kasus Usahatani Lahan Pekarangan di Kecamatan Kerinci Kabupaten Pelalawan). Indonesian Jurnal of Agricultural Economics (IJAE). [Internet]. [Diunduh 2014 Mar 2]; Vol 2(2): Fakultas Pertanian, Universitas Riau Pekanbaru(ID). Tersedia pada: http://ejournal.unri. ac.id/index.php/IJAE/article/viewFile/1552/1527

Dimyati. 2013. Prestasi Indeks Pembangunan Manusia. Jurnal Nasional. [Internet]. [Diunduh 2014 Sep 29]. Tersedia pada: http://www.jurnas.com/ halaman/11/2013-03-20/237259

Fadli GM. 2010. Kepemimpinan dan Partisipasi Masyarakat dalam Pembangunan Desa di Kawasan Perbatasan Indonesia-Malaysia (Kasus Pembangunan Kesehatan di Desa Nanga Bayan, Kecamatan Ketungau Hulu, Kabupaten Sintang, Provinsi Kalimantan Barat)[Tesis]. Bogor (ID): Mayor Sosiologi Pedesaan, Fakultas Ekologi Manusia, Institut Pertanian Bogor.

Fatchiya A. 2010. Pola Pengembangan Kapasitas Pembudidaya Ikan Kolam Air Tawar di Provinsi Jawa Barat. [Disertasi]. [Internet]. [Diunduh 2014 Feb 23]: Fakultas Ekologi Manusia, Institut Pertanian Bogor (ID). Tersedia pada: http://repository.ipb. ac.id/bitstream/handle/123456789/55017/2010afa. df? sequence $=1$

Fetterman DM, Wandersman A. 2005. Empowerment Evaluation Principles in Practice. New York, London(US): The Guilford Press.

Hermanto dan Swastika Dewi KS. 2011. Farmers'Groups Empowerment as an Initial Step to Farmers'Welfare Improvement. Jurnal Analisis Kebijakan Pertanian. [Internet]. [Diunduh 2014 Feb 13]; Vol 9(4): Pusat Sosial Ekonomi dan Kebijakan Pertanian Bogor (ID). Tersedia pada: http://pse.litbang.deptan.go.id/ ind/pdffiles/ART9-4e.pdf
Hessel NS, Tangkilisan. 2007. Manajemen Publik. Jakarta(ID): PT Grasindo.

Korten, David C. 1987. Community Management: Asian Experience and Perspective. West Harford(US): Connecticut. Kumarian Press.

Mulyadi D, Rivai V. 2012. Kepemimpinan dan Perilaku Organisasi. Jakarta(ID): Rajawali Press.

[Permentan] Peraturan Menteri Pertanian Nomor 82 Tahun 2013 Tentang Pedoman Pembinaan Kelompok Tani dan Gabungan Kelompok Tani. BKP5K Kabupaten Bogor(ID)

Pratama C. 2013. Faktor-faktor yang Mempengaruhi Keberhasilan Pemberdayaan Perempuan Desa Joho di Lereng Gunung Wilis. Jurnal Kebijakan dan Manajemen Publik. [Internet]. [Diunduh 2013 Okt 7]; Vol 1(01): FISIP Universitas Airlangga Surabaya(ID). Tersedia pada: http://journal.unair. ac.id/article-4586-media138-category 138.html

Singarimbun M, Effendi S. 1989. Metode Penelitian Survai. Jakarta(ID): LP3S

Sitorus F. 1998. Penelitian Kualitatif "Suatu Perkenalan". Kelompok dokumentasi Ilmu-Ilmu sosial untuk Laboratorium Sosiologi, Antropologi dan Kependudukan Jurusan Ilmu Sosial Dan Ekonomi Pertanian, Fakultas Pertanian IPB.

Setiana L. 2005. Teknik Penyuluhan dan Pemberdayaan masyarakat. Bogor(ID): Ghalia Indonesia.

Suharto E. 2005. Membangun Masyarakat Memberdayakan Rakyat Kajian Strategis Pembangunan Kesejahteraan Sosial dan Pekerjaan Sosial. Bandung (ID): PT Refika Aditama.

Soetomo. 2012. Pembangunan Masyarakat 'Merangkai Sebuah Kerangka'. Yogyakarta(ID) : Pustaka Pelajar.

Sumodiningrat G. 1999. Pemberdayaan Masyarakat dan Jaringan Pengamanan Sosial. Jakarta: PT Gramedia Pustaka Utama.

Tampubolon J. 2006. Pemberdayaan Masyarakat Melalui Pendekatan Kelompok: Kasus Pemberdayaan Masyarakat Miskin Melalui Pendekatan Kelompok Usaha Bersama (KUBE) [Disertasi]. Fakultas Ekologi Manusia, Institut Pertanian Bogor (ID).

Tohani E. 2012. Kapasitas Kultural Pemimpin Informal dalam Mewujudkan Masyarakat Harmonis.Jurnal Pembangunan Pendidikan: Fondasi dan Aplikasi. [internet]. [Diunduh 2013 Okt 4]; Vol 01(1): Fakultas Ilmu Sejarah Universitas Negeri Yogyakarta(ID). Tersedia pada: http://journal.uny.ac.id/index.php/ jppfa//article/download/1048/850

Utama S. 2008. Pemberdayaan Masyarakat Sekitar Hutan Melalui Pendekatan Kelompok (Kasus Pengelolaan Hutan Bersama Masyarakat pada Areal Hutan Produksi Perhutani Unit I Provinsi Jawa Tengah) [Disertasi]. Fakultas Ekologi Manusia, Institut 
Pertanian Bogor.

Utami HN. 2006. Keberdayaan, Kemajuan, dan Keberlanjutan Usaha Pengrajin: Kasus Kabupaten Sidoarjo dan Kabupaten Magetan Provinsi Jawa Timur[Disertasi]. Fakultas Ekologi Manusia, Institut Pertanian Bogor(ID).

[UU] Undang-Undang Nomor 16 Tahun 2006 Tentang Sistem Penyuluhan Pertanian, Perikanan, dan Kehutanan. BKP5K Kabupaten Bogor(ID)

Widjajanti S. 2011. Model Pemberdayaan Masyarakat. Jurnal Ekonomi Pembangunan. [Internet]. [Diunduh 2013 Des 3]; Vol 12(01): Fakultas Ekonomi Universitas Semarang (ID). Tersedia pada: http:// publikasiilmiah.ums.ac.id/bitstream/handle/-Kesi1. pdf 